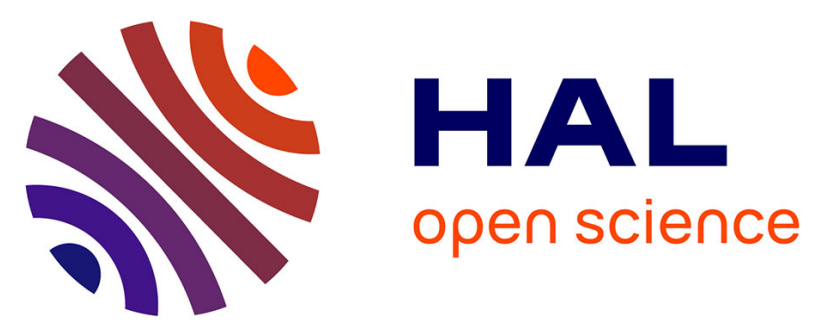

\title{
Paracyclophane-based Silver Phosphates as Catalysts for Enantioselective Cycloisomerization/Addition Reactions: Synthesis of Bicyclic Furans
}

Guillaume Force, Yvette Lock Toy Ki, Kevin Isaac, Pascal Retailleau, Angela Marinetti, Jean-François Betzer

\section{- To cite this version:}

Guillaume Force, Yvette Lock Toy Ki, Kevin Isaac, Pascal Retailleau, Angela Marinetti, et al.. Paracyclophane-based Silver Phosphates as Catalysts for Enantioselective Cycloisomerization/Addition Reactions: Synthesis of Bicyclic Furans. Advanced Synthesis and Catalysis, 2018, 360 (17), pp.3356-3366. 10.1002/adsc.201800587 . hal-02152287

\section{HAL Id: hal-02152287 \\ https://hal.science/hal-02152287}

Submitted on 20 Sep 2019

HAL is a multi-disciplinary open access archive for the deposit and dissemination of scientific research documents, whether they are published or not. The documents may come from teaching and research institutions in France or abroad, or from public or private research centers.
L'archive ouverte pluridisciplinaire HAL, est destinée au dépôt et à la diffusion de documents scientifiques de niveau recherche, publiés ou non, émanant des établissements d'enseignement et de recherche français ou étrangers, des laboratoires publics ou privés. 
DOI: 10.1002/adsc.201800587

\title{
Paracyclophane-based Silver Phosphates as Catalysts for Enantioselective Cycloisomerization/Addition Reactions: Synthesis of Bicyclic Furans
}

\author{
Guillaume Force, ${ }^{\mathrm{a}}$ Yvette Lock Toy Ki, ${ }^{\mathrm{a}}$ Kévin Isaac, ${ }^{\mathrm{a}}$ Pascal Retailleau, ${ }^{\mathrm{a}}$ Angela \\ Marinetti $^{\mathrm{a}, *}$ and Jean-François Betzer ${ }^{\mathrm{a}, *}$ \\ a Institut de Chimie des Substances Naturelles, ICSN-CNRS UPR 2301, Université Paris-Sud, Université Paris-Saclay \\ 1, av. de la Terrasse, 91198 Gif-sur-Yvette (FRANCE) \\ Fax: (+33)-1-6907-7247; phone: (+33)-1-6982-3036; E-mail: angela.marinetti@cnrs.fr \\ Fax: (+33)-1-6907-7247; phone: (+33)-1-6982-3065; E-mail: jean-francois.betzer@cnrs.fr
}

Received: May 4, 2018; Revised: June 11, 2018; Published online: July 11, 2018

Supporting information for this article is available on the WWW under http://dx.doi.org/10.1002/adsc.201800587

\begin{abstract}
This manuscript discloses the first uses of chiral phosphates based on C2-symmetric paracyclophane scaffolds as chiral counterions in transition metal catalysis, showing that they may compare favorably with other known chiral phosphates, such as the TRIP phosphate. The targeted catalytic reaction is a silver(I) promoted domino heterocyclization of 2-(1-alkynyl)-2-alken-1-one derivatives, in the presence of $C$-, or $N$-nucleophiles, which provides an efficient access to substituted bicyclic furans. Results show that high levels of enantioselectivity can be attained with either paracyclophanebased phosphates or TRIP phosphates, when the nucleophilic reactants display N-H functions in appropriate positions, near to the nucleophilic center. Therefore, the involvement of H-bonding between the $\mathrm{NH}$ function and the phosphate in the enantiodetermining step is postulated.
\end{abstract}

Keywords: Asymmetric catalysis; chiral phosphates; silver; paracyclophane; furan

\section{Introduction}

During the last few years, our research group has developed a new family of planar chiral paracyclophanes embedding phosphorus functions in a $C_{2}$-symmetric paracyclophane framework. The first goal of this research program has been to access phosphoric acids of this class. We have developed synthetic pathways to paracyclophanes I and II in which one of the chains tethering the aromatic rings is a three atom O-P-O sequence and the other one a 1,8 -biphenylenediyl ${ }^{[1]}$ or 1,1 '-ferrocenediyl moiety ${ }^{[2]}$ respectively (Figure 1). ${ }^{[3]}$ The planar chirality is generated here by the presence of the pseudo-ortho substituents $\mathrm{R}$ on the paracyclophane, close to the catalytic center. The phosphoric acids I and II have been used as organocatalysts in the asymmetric $\mathrm{H}$ transfer hydrogenation of quinolines, as well as in enantioselective $a z a$-Friedel-Crafts reactions between indoles and imines, with up to $92 \%$ and $98 \%$ enantiomeric excesses respectively. ${ }^{[2 \mathrm{~b}, 2 \mathrm{c}]}$

In further studies, we have prepared planar chiral phosphoramidites based on the same scaffolds. ${ }^{[4]}$ They served as monodenatate ligands in gold complexes (III, Figure 1) that proved to be good catalysts for the cycloisomerisation of $N$-tethered prochiral dienynes into bicyclo[4.1.0]heptanes displaying three contiguous stereogenic centers.
Excellent diastereoselectivity and up to $95 \%$ enantiomeric excess have been obtained. Overall, these results have validated our design of paracyclophane based chiral auxiliaries in the two different fields of Brønsted acid organocatalysis and gold(I) catalysis.
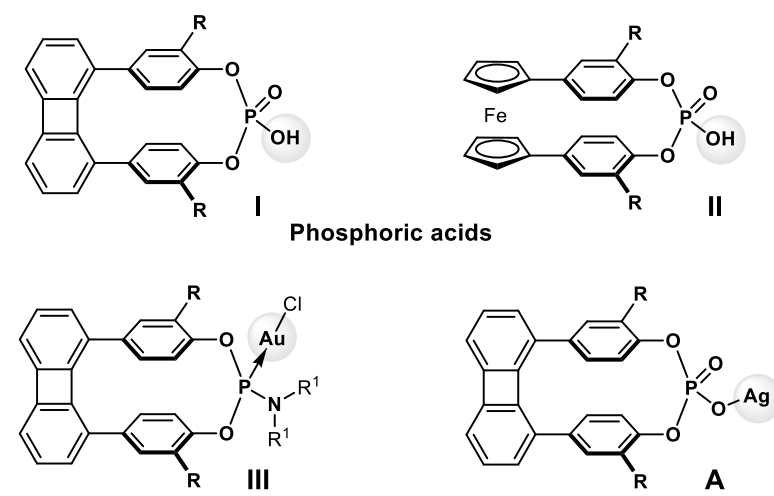

Phosphoramidite gold(I) complexes

Silver phosphates (this work)

Figure 1. Phosphoric acid and phosphoramidite derivatives with planar chiral paracyclophane scaffolds.

In line with these previous studies, we have envisioned to evaluate the potential of the same chiral auxiliaries in a third domain: the counterion directed 
asymmetric transition metal catalysis. ${ }^{[5]}$ In this field indeed, chiral phosphates ${ }^{[6]}$ play a central role, notably for reactions triggered by activation of carbon-carbon $\pi$-systems with gold ${ }^{[5 a, 7]}$ or silver catalysts. ${ }^{[8]}$

We disclose hereafter the high efficiency of the silver phosphate A (Figure 1) as chiral catalyst for the reaction of 2-(1-alkynyl)-2-alken-1-ones with nucleophilic trapping reagents. As shown in Scheme 1, this domino process involves a 5-endo-dig heterocyclization followed by trapping of a cationic vinyl metal intermediate by the nucleophile. It represents a highly convenient method for the synthesis of substituted furans including bicyclic species. ${ }^{[9]}$

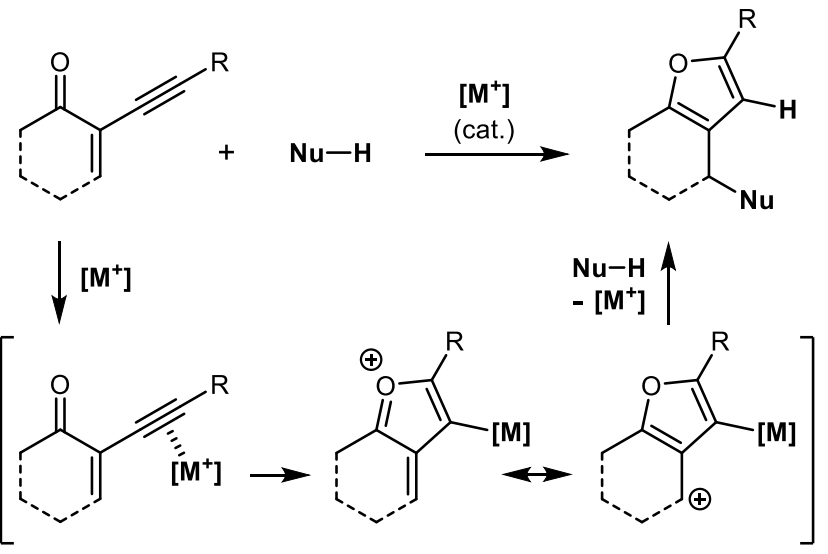

Scheme 1. Domino cyclization of 2-(1-alkynyl)-2-alken-1ones/nucleophile addition, catalyzed by transition metals.

Within these studies, we have also extended the domino heterocyclization/nucleophilic addition reactions to other series of nucleophiles, which expands the synthetic potential of these processes. In 2004 Larock et al. first reported that the transition metal-promoted cyclization of 2-alkynyl-enones in the presence of nucleophiles leads to substituted furans (Scheme 1). ${ }^{[9]}$ This domino sequence was carried out initially with $\mathrm{AuCl}_{3}$ as the catalyst and either alcohols or electron rich aromatic derivatives as nucleophiles. Since then, other transition metals, like copper(I) ${ }^{[10]}$ platinum(II),${ }^{[11]}$ palladium(II),${ }^{[12]}$ silver(I) ${ }^{[3]}$ and rhodium $(\mathrm{I})^{[14]}$ have been employed successfully and the use of $\mathrm{Au}$ (III) catalysts has been extended. ${ }^{[15]}$ Alcohols, electron-rich aromatics and heteroaromatics remain the most common nucleophiles, while electrophiles other than protons have been considered also for the final $\mathrm{M}-\mathrm{C}$ bond cleavage. Gold(I) catalysts were rather used to convert 2-alkynyl-enones into 1,3-dipoles which were engaged in cycloaddition reactions with various dipolarophiles. ${ }^{[16]}$ Asymmetric versions of these 1,3dipolar cycloadditions have also been developed using chiral phosphine or phosphoramidite gold complexes. ${ }^{[17]}$

The only asymmetric version of the domino heterocyclization/nucleophilic addition shown in
Scheme 1 has been reported by Toste et al. in 2011, using a chiral copper(II)-TRIP catalyst and indoles as the nucleophiles (TRIP = 3,3'-bis(2,4,6triisopropylphenyl)-1,1'-bi-2-naphthol cyclic phosphate). ${ }^{18]}$ The scarce development of asymmetric variants for this sequence, as well as the huge synthetic potential of these reactions in the context of furans chemistry, ${ }^{[19]}$ led us to choose them as benchmark tests to evaluate planar chiral phosphates I and II as chiral counterions. Moreover, to apply the counterion strategy to these reactions seems to be fully relevant, based on mechanistic concerns also. According to the postulated mechanism (Scheme 1), the enantiodetermining step should be indeed the addition of the nucleophile on the carbocationic intermediate, which implies close proximity between the reacting site and the counteranion, forming a tight ion pair. On the contrary, the metal catalyst will be rather far from the reacting center, which may prevent the classical chiral ligand-based strategy to succeed.

\section{Results and Discussion}

For initial tests, we have considered both gold(I) and silver(I) phosphates. For comparison purposes, the corresponding TRIP derived catalysts $\left(\mathrm{Ph}_{3} \mathrm{P}\right) \mathrm{AuMe} /(R)$-III and $(R)-\mathbf{C}$ have been tested also. The $\left(\mathrm{PPh}_{3}\right) \mathrm{Au}(\mathrm{I})$ phosphates have been generated in situ from the commercially available $\left(\mathrm{Ph}_{3} \mathrm{P}\right) \mathrm{AuMe}$ and phosphoric acids $\left(R_{\mathrm{p}}\right)-\mathbf{I a},\left(S_{\mathrm{p}}\right)-\mathbf{I I a}(\mathrm{R}=$ metaterphenyl) and $(R)$-III. ${ }^{20]}$ This procedure was preferred over anion exchange between $\mathrm{Ph}_{3} \mathrm{PAuCl}$ and silver phosphates in order to avoid background reactions promoted by silver(I).

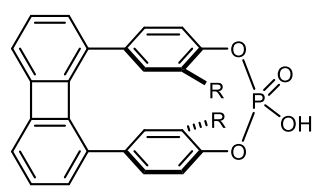

$\left(R_{\mathrm{p}}\right)$-la $\mathrm{R}=m$-terpheny

$[\alpha]_{D}^{20}=-88\left(c=0.5, \mathrm{CHCl}_{3}\right)$

${ }^{31} \mathrm{P}$ NMR $\delta=11.4 \mathrm{ppm}$
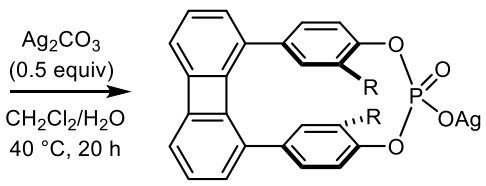

$\left(R_{\mathrm{p}}\right)-\mathrm{A} \quad \mathrm{R}=m$-terphenyl

${ }^{31} \mathrm{P}$ NMR $\delta=-1.2 \mathrm{ppm}$
$[\alpha]_{D}^{20}=-79\left(c=0.5, \mathrm{CHCl}_{3}\right)$

Scheme 2. Preparation of the silver phosphate $\left(R_{\mathrm{p}}\right)$-A. The same procedure has been used for the synthesis of $\left(S_{\mathrm{p}}\right)-\mathbf{B}^{\mathbf{1}}$, $\left(S_{\mathrm{p}}\right)-\mathbf{B}^{2}$ and $(R)-\mathbf{C}$.

The silver phosphates $\left(R_{\mathrm{p}}\right)-\mathbf{A},\left(S_{\mathrm{p}}\right)-\mathbf{B}^{\mathbf{1}}\left(\mathrm{R}=\mathrm{SiPh}_{3}\right)$ and $\left(S_{\mathrm{p}}\right)-\mathbf{B}^{2} \quad(\mathrm{R}=$ meta-terphenyl) have been prepared from the corresponding phosphoric acids and silver carbonate, as typified in Scheme 2. The phosphoric acids have been reacted with silver carbonate in a mixture of dichloromethane and distilled water, at $40{ }^{\circ} \mathrm{C}$ for $20 \mathrm{~h}$. The solvents have been evaporated under reduced pressure and the crude silver phosphates have been used in the catalytic tests without further purification. ${ }^{[21]}$ 
Preliminary experiments were performed on the model substrates 2-(phenylethynyl)cyclohex-2-enone 1a and $1 H$-indole 2a. ${ }^{[9 a]}$ All the reactions have been carried out in toluene at room temperature with 10 mol\% catalyst. The main results are reported in table 1. The two gold(I) catalysts, $\left(\mathrm{Ph}_{3} \mathrm{P}\right) \mathrm{AuMe} / \mathrm{Ia}$ and $\left(\mathrm{Ph}_{3} \mathrm{P}\right) \mathrm{AuMe} / \mathrm{IIa}$ gave high catalytic activity but disappointing levels of enantioselectivity (ee $<10 \%$, entries 1 and 2), irrespective of the presence of 1,1'ferrocenediyl or 1,8-biphenylenediyl moiety in the phosphate scaffold. The gold complex $\left(\mathrm{Ph}_{3} \mathrm{P}\right) \mathrm{AuMe} / \mathrm{III}$ bearing TRIP as the counterion afforded slightly higher, but still very moderate enantioselectivity ( $24 \%$ ee, entry 3 ).

Table 1. Screening of metal phosphates in the reaction of 1a with indole $2 \mathbf{a}$.

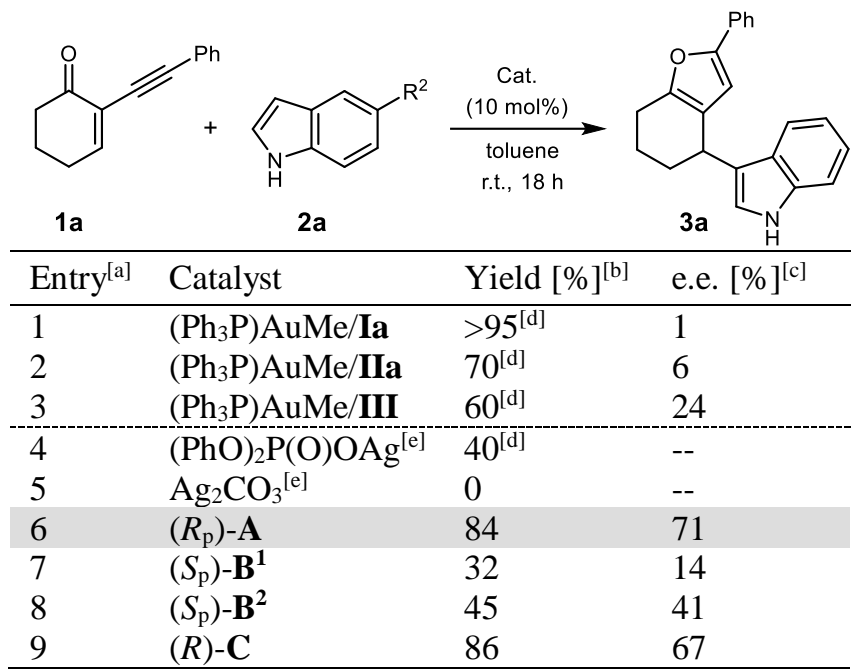

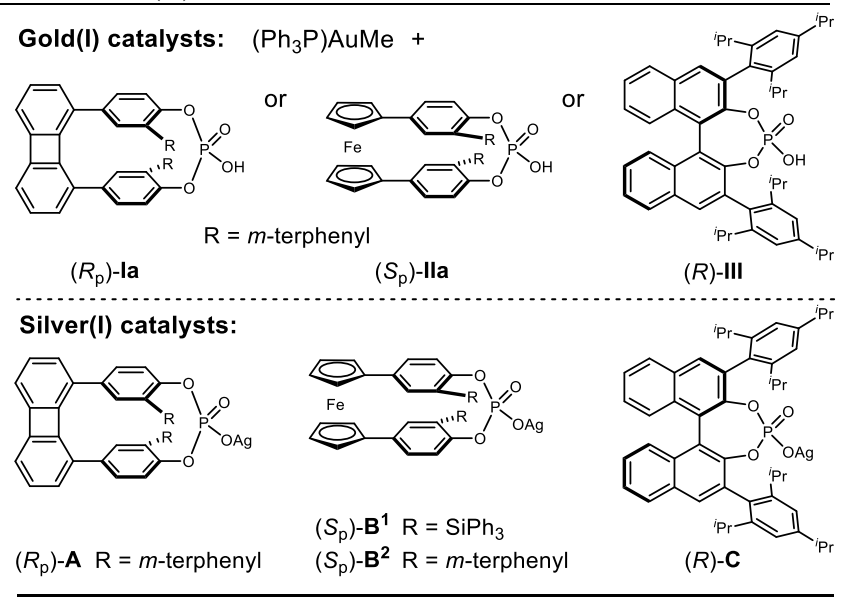

[a] Reaction conditions: 1a $(0.05 \mathrm{mmol}), \mathbf{2 a}(0.05 \mathrm{mmol})$, catalyst $(10 \mathrm{~mol} \%)$ in toluene $(0.5 \mathrm{~mL})$ at room temperature for $18 \mathrm{~h}$. MS $4 \AA$ (10 mg) was added for $\mathrm{Ag}(\mathrm{I})$ catalyzed reactions. ${ }^{[b]}$ Isolated yield. ${ }^{[c]}$ Determined by HPLC on CHIRALPAK IA. [d] Yield determined by ${ }^{1} \mathrm{H}$ NMR with 1,3,5-trimethoxybenzene as internal standard added at the end of the reaction. ${ }^{\text {e] }} \mathrm{In} \mathrm{CH}_{2} \mathrm{Cl}_{2}$.

Moving then to silver catalysts, as a blank test we have ascertained at first that $\mathrm{Ag}_{2} \mathrm{CO}_{3}$, the silver salt used to generate the chiral phosphates, does not promote the catalytic reaction (entry 5). ${ }^{[2]}$ Then, the chiral silver phosphates have been screened. Planar chiral phosphates with 1,1'-ferrocenediyl tethers $\left(S_{\mathrm{p}}\right)$ $\mathbf{B}^{1}$ and $\left(S_{\mathrm{p}}\right)-\mathbf{B}^{2}$ were moderately active, but afforded 3a with higher enantiomeric excess, with respect to the corresponding gold(I) catalysts (ee 14 and $41 \%$, respectively, entries 7 and 8). The low catalytic activity of these phosphates might be due to oxidation of the ferrocenyl moiety by silver(I), as a result of the close redox potential of the ferrocenium/ferrocene and $\mathrm{Ag}^{+} / \mathrm{Ag}$ couples. ${ }^{[23]}$ The 1,8-biphenylenediyl tethered silver phosphate $\left(R_{\mathrm{p}}\right)$-A displayed the most satisfying behavior, both in terms of catalytic activity and enantioselectivity: it provided compound $\mathbf{3 a}$ in $84 \%$ yield, with $71 \%$ ee (entry 6 ). The TRIP-based silver catalyst $(R)-\mathbf{C}$ also displayed good catalytic activity (86\% yield) but afforded a slightly lower enantiomeric excess $(67 \%$ ee, entry 9). For comparison purposes, it can be noticed that silver diphenyl phosphate gives an isolated yield of only $40 \%$ under the same reaction conditions (entry 4).

The encouraging results obtained with the silver phosphate $\left(R_{\mathrm{p}}\right)$-A led us to carry out further optimization of the reaction conditions, by studying at first the effect of solvents. From the results reported in Table 2, it can be noticed that halogenated aromatic solvents gave good yields and improved enantiomeric excesses (entries 1-3). Especially chlorobenzene afforded 3a in $94 \%$ yield with $78 \%$ ee. THF, AcOEt and $\mathrm{MeNO}_{2}$ gave lower conversion rates but retained high enantiomeric excesses (entries 4-6). The best result, in terms of enantioselectivity, was obtained with cis-1,2-dichloroethylene as the solvent (entry 11). Decreasing the reaction temperature to $0{ }^{\circ} \mathrm{C}$ did not improve the enantiomeric excess (entry 12). Finally, the highest, $86 \%$ enantiomeric excess was obtained in cis-1,2-dichloroethylene without addition of molecular sieve (entry $13,83 \%$ yield).

Table 2. Optimization of the reaction conditions using $\left(R_{\mathrm{p}}\right)-\mathrm{A}$ as the catalyst.

\begin{tabular}{llll}
\hline Entry $^{[\mathrm{a}]}$ & Solvent & $\begin{array}{l}\text { Yield } \\
{[\%]^{[\mathrm{b}]}}\end{array}$ & $\begin{array}{l}\text { e.e. } \\
{[\%]^{[\mathrm{c}]}}\end{array}$ \\
\hline 1 & Fluorobenzene & 77 & 76 \\
2 & Chlorobenzene & 94 & 78 \\
3 & $\alpha, \alpha, \alpha-$ Trifluorotoluene & $>95^{[\mathrm{f}]}$ & 71 \\
4 & EtOAc & 47 & 76 \\
5 & $\mathrm{THF}$ & 53 & 73 \\
6 & $\mathrm{CH}_{3} \mathrm{NO}_{2}$ & 45 & 80 \\
7 & $\mathrm{CCl}_{4}$ & 78 & 67 \\
8 & $\mathrm{CHCl}_{3}$ & 56 & 79 \\
9 & $\mathrm{CH}_{2} \mathrm{Cl}_{2}$ & 84 & 76 \\
10 & $1,2-D i c h l o r o e t h a n e$ & 87 & 80 \\
11 & cis-1,2-Dichloroethylene & $>95^{[\mathrm{f}]}$ & 82 \\
$12^{[\mathrm{d}]}$ & cis-1,2-Dichloroethylene & $>95^{[\mathrm{f}]}$ & 81 \\
$13^{[\mathrm{e}]}$ & cis-1,2-Dichloroethylene & 83 & 86 \\
\hline
\end{tabular}

[a] Reaction conditions: 1a $(0.10 \mathrm{mmol}), \mathbf{2 a}(0.10 \mathrm{mmol})$, $\left(R_{\mathrm{p}}\right)$-A $(10 \mathrm{~mol} \%)$ and $4 \AA(20 \mathrm{mg})$, solvent $(1 \mathrm{~mL})$ at room temperature for $18 \mathrm{~h} .{ }^{[\mathrm{b}]}$ Isolated yield. ${ }^{[\mathrm{c}]}$ Determined by HPLC on CHIRALPAK IA. ${ }^{[\mathrm{d}]}$ At $0{ }^{\circ} \mathrm{C}$. ${ }^{[\mathrm{e}]}$ Without MS. [f] NMR yield. 
Under these optimized conditions, the enantioselective reaction has been extended to a few substituted indoles as the nucleophiles (Scheme 3). Racemic samples have been obtained using $\mathrm{AgPF}_{6}$ as the catalyst, which gives satisfying yields of the desired products under mild conditions (e.g. 84\% yield for 3e, see Experimental Section). When using the planar chiral catalyst $\left(R_{\mathrm{p}}\right)$-A, with indoles bearing both electron-withdrawing and electron-donating substituents on their 5-position, the resulting products 3b-d were isolated in good yields and in a satisfactory range of enantiomeric excess from 82$86 \% .{ }^{[2]}$ However, a significant drop of the enantiomeric excess was observed with $N$ methylindole as the nucleophile $(39 \%$ ee $){ }^{[25]}$ which highlights a possible role of the $\mathrm{NH}$ function in stereocontrol (see below). Two other 2-(1-alkynyl)-2alken-1-ones as substrates $\left(\mathrm{R}^{1}=4-\mathrm{MeO}-\mathrm{C}_{6} \mathrm{H}_{4}\right.$ and $\left.\mathrm{Ph}-\mathrm{CH}_{2}-\right)$ have been used but lower enantiomeric excesses were observed.

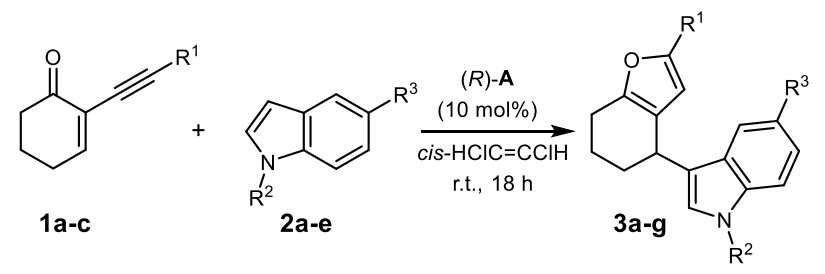

$\begin{array}{llll}\text { 3a, } \mathrm{R}^{1}=\mathrm{Ph}, & \mathrm{R}^{2}=\mathrm{H}, & \mathrm{R}^{3}=\mathrm{H}, & 83 \% \text { yield, } 86 \% \text { ee } \\ \text { 3b, } \mathrm{R}^{1}=\mathrm{Ph}, & \mathrm{R}^{2}=\mathrm{H}, & \mathrm{R}^{3}=\mathrm{Me}, & 95 \% \text { yield, } 86 \% \text { ee } \\ \text { 3c, } \mathrm{R}^{1}=\mathrm{Ph}, & \mathrm{R}^{2}=\mathrm{H}, & \mathrm{R}^{3}=\mathrm{F}, & 97 \% \text { yield, } 82 \% \text { ee } \\ \text { 3d, } \mathrm{R}^{1}=\mathrm{Ph}, & \mathrm{R}^{2}=\mathrm{H}, & \mathrm{R}^{3}=\mathrm{OMe}, & 79 \% \text { yield, } 84 \% \text { ee } \\ \text { 3e, } \mathrm{R}^{1}=\mathrm{Ph}, & \mathrm{R}^{2}=\mathrm{Me}, & \mathrm{R}^{3}=\mathrm{H}, & 27 \% \text { yield, } 39 \% \text { ee } \\ \text { 3f, } \mathrm{R}^{1}=4-\mathrm{MeO}-\mathrm{C}_{6} \mathrm{H}_{4}, & \mathrm{R}^{2}=\mathrm{H}, & \mathrm{R}^{3}=\mathrm{H}, & 67 \% \text { yield, } 74 \% \text { ee } \\ \text { 3g, } \mathrm{R}^{1}=\mathrm{Ph}-\mathrm{CH}_{2}, & \mathrm{R}^{2}=\mathrm{H}, & \mathrm{R}^{3}=\mathrm{H}, & 47 \% \text { yield, } 60 \% \text { ee }\end{array}$

Scheme 3. Enantioselective synthesis of 3b-e using the silver phosphate $\left(R_{\mathrm{p}}\right)$-A as the catalyst.

As a next step, we have envisioned to investigate more diverse nucleophilic species in the same reaction. Concerning $N$-nucleophiles, as far as we know, only aniline derivatives have been used previously using platinum(II) dichloride ${ }^{[11 a]}$ or silver(I) triflates and nitrates as the catalysts. ${ }^{[13 a, 13 c]}$ No asymmetric variant of these reactions has been reported so far. Thus, we have considered at first the reaction of 1a with aniline, and we have extended then the reaction to tosylamide, tert-butyl carbamate and benzyl carbamate (Scheme 4), ${ }^{[26]}$ since these groups may open wider synthetic perspectives to the resulting bicyclic furans. It must be noted indeed that 3-aminomethyl furans represent an especially relevant class of bioactive compounds, which includes notably CRF1 receptor antagonists for the treatment of anxiety disorders, ${ }^{[27]}$ TRPM8 antagonists for pain relief ${ }^{[28]}$ and glucagon antagonists for type II diabetes treatment. ${ }^{[29]}$

We have demonstrated that tert-butyl carbamate and benzyl carbamate deliver the desired furans $\mathbf{4 b}$ and $\mathbf{4 c}$ through very clean processes $(87 \%$ and $76 \%$ yields) when using $\mathrm{AgPF}_{6}$ as the catalyst (entries 4 and 7), in spite of the low nucleophilic character of these species. The molecular structures of $\mathbf{4 b}$ and $\mathbf{4 c}$ have been unambiguously established by singlecrystal X-ray analysis (Figure 2). ${ }^{[30]}$ Also, $p$ toluenesulfonamide can serve as a suitable $N$ nucleophile giving the expected product $\mathbf{4 d}$ in nearly quantitative yield (entry 10). The good reactivity observed here with silver hexafluorophosphate should be considered against the lack of reactivity reported previously with palladium(II) catalysts. ${ }^{[12 c]}$ Thus, in this case, the silver catalyst expands the scope of $N$ nucleophiles in this domino reaction.

Concerning the enantioselective variants carried out with the planar chiral catalyst $\left(R_{\mathrm{p}}\right)$ - $\mathrm{A}$, both aniline and $p$-tosylamide gave very low ees (entries 2 and 11 in Table 3). Tert-butyl and benzyl carbamates afford enantiomeric excesses in the range 43-52\% with both the silver phosphate $\left(R_{\mathrm{p}}\right)-\mathrm{A}$ and the TRIP derived silver salt $(R)-\mathbf{C}$ (entries 5, 6, 8 and 9 ).

Table 3. Domino cycloisomerization/addition reactions with $N$-nucleophiles, including enantioselective reactions.
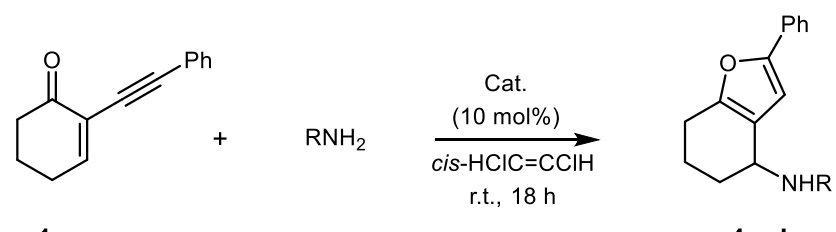

\begin{tabular}{|c|c|c|c|c|c|}
\hline 1a & & & & & $a-d$ \\
\hline Entry $^{[\mathrm{a}]}$ & Product & $\mathrm{R}$ & Catalyst & $\begin{array}{l}\text { Yield } \\
{[\%]^{[b]}}\end{array}$ & $\begin{array}{l}\text { e.e. } \\
{[\%]^{[\mathrm{c}]}}\end{array}$ \\
\hline 1 & & & $\left.\mathrm{AgPF}_{6}{ }^{[\mathrm{d}]}\right]$ & 89 & -- \\
\hline 2 & $4 a$ & $\mathrm{Ph}$ & $\left(R_{\mathrm{p}}\right)-\mathbf{A}$ & 84 & 1 \\
\hline 3 & & & $(R)-\mathbf{C}$ & 75 & 11 \\
\hline 4 & & & $\mathrm{AgPF}_{6}{ }^{[\mathrm{d}]}$ & 87 & -- \\
\hline 5 & $4 b$ & $\mathrm{CO}_{2} t-\mathrm{Bu}$ & $\left(R_{\mathrm{p}}\right)-\mathbf{A}$ & 18 & 46 \\
\hline 6 & & & $(R)-\mathbf{C}$ & 15 & 50 \\
\hline 7 & & & $\mathrm{AgPF}_{6}{ }^{[\mathrm{d}]}$ & 76 & -- \\
\hline 8 & $4 c$ & $\mathrm{CO}_{2} \mathrm{CH}_{2} \mathrm{Ph}$ & $\left(R_{\mathrm{p}}\right)-\mathbf{A}$ & 28 & 43 \\
\hline 9 & & & $(R)-\mathbf{C}$ & 24 & 52 \\
\hline 10 & & & $\mathrm{AgPF}_{6}{ }^{[\mathrm{d}]}$ & 94 & -- \\
\hline 11 & $4 d$ & $p$-Tosyl & $\left(R_{\mathrm{p}}\right)-\mathbf{A}$ & 21 & 8 \\
\hline 12 & & & $(R)-\mathbf{C}$ & NR & -- \\
\hline
\end{tabular}

[a] Reaction conditions: 1a $(0.10 \mathrm{mmol}), \mathrm{RNH}_{2}(0.10$ $\mathrm{mmol})$, catalyst (10 mol\%) in cis-1,2-dichloroethylene (1 $\mathrm{mL}$ ) at room temperature for $18 \mathrm{~h} .{ }^{[b]}$ Isolated yield. ${ }^{[c]}$ Determined by chiral HPLC. ${ }^{[\mathrm{d}]} \mathrm{In} \mathrm{CH}_{2} \mathrm{Cl}_{2}$.
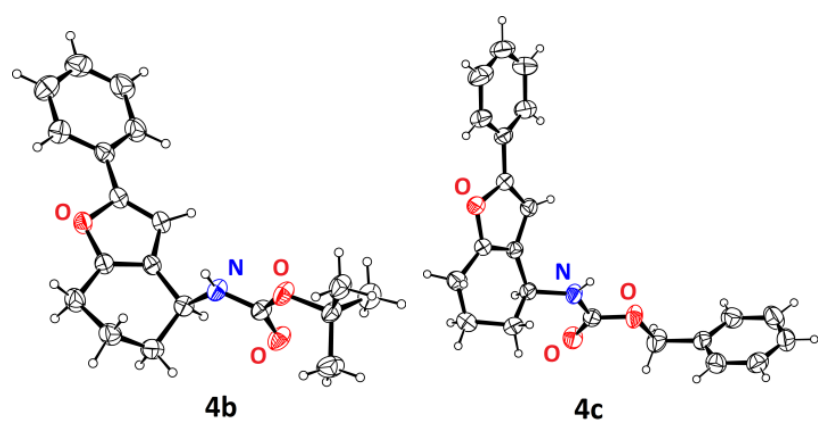

Figure 2. ORTEP drawing of compounds $4 \mathbf{b}$ and $\mathbf{4 c}$. 
The moderate to low enantiomeric excesses obtained with these $N$-nucleophiles, as well as the significant decrease of the enantioselectivity previously observed with $N$-methylindole, with respect to $\mathrm{N}$-unsubstituted indoles (see Scheme 3), might be assigned to the lack of free $\mathrm{NH}$ functions close to the nucleophilic center in these substrates. We can postulate that the $\mathrm{NH}$ group of $\mathrm{N}$ unsubstituted indoles will enable hydrogen bonding with the phosphoryl moiety of the silver phosphate in the enantiodetermining addition step shown in Figure 3 . The H-bonding, combined with a tight ion pairing of the phosphate with the cationic intermediate, will generate a better-defined relative orientation of the substrates in the transition state and therefore crucially contribute to chiral induction.

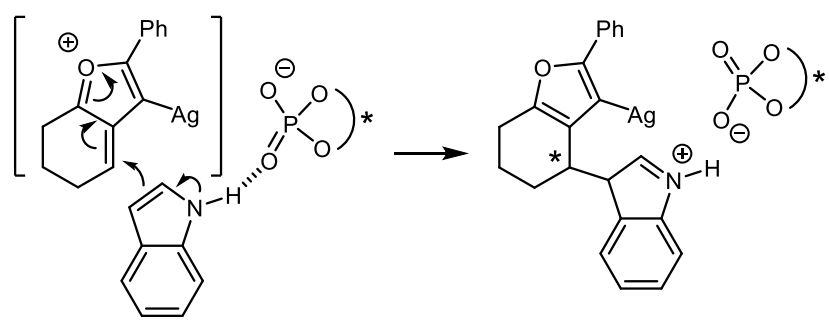

Figure 3. Postulated enantiodetermining step in the domino cycloisomerization/nucleophilic addition of indole to $\mathbf{1 a}$.

Based on this hypothesis, one may postulate that other nucleophilic substrates with H-bonding functions in appropriate positions with respect to their nucleophilic sites, might also undergo addition to 1a with high stereocontrol.

In order to support this hypothesis, we have considered ortho-( $N$-acetylamino)aniline as the nucleophile in the reaction with 1a. The results in Table 4, entries 3 and 4, show that the H-bonding function in ortho-position to the nucleophilic amine group, does not change significantly the enantiomeric excess given by the planar chiral catalyst $\left(R_{\mathrm{p}}\right)-\mathbf{A}$. However, the TRIP-derived silver phosphate $(R)-\mathbf{C}$ affords compound $4 \mathrm{e}$ with a remarkably high, $90 \%$ enantiomeric excess. In this case, the H-bonding adduct with the substrate might be responsible for the good stereochemical control. Additional support to this hypothesis has been afforded by entries 5 and 6 in Table 4, showing that the analogous meta- and para-( $N$-acetylamino)anilines, which display remote acetamido substituents, are converted into the corresponding bicyclic furans in only low enantiomeric excesses (21\% and 6\% ee with $(R)-\mathbf{C}$ as the catalyst). Obviously, the effects of H-bonding (if any) will depend on the structural features of the catalyst/substrate pairs and, therefore, the low enantioselectivity obtained with $\left(R_{\mathrm{p}}\right)$-A (entry 3$)$ can be assigned to a less suitable spatial arrangement of the corresponding adduct, with respect to catalyst $(R)-\mathbf{C}$.
These results highlight the possibly beneficial effect of an $\mathrm{N}$-acylamino substituent on the aniline used as the nucleophile, provided that this group is suitably positioned, near to the nucleophilic center. In the future, these preliminary results might found the design of new nucleophilic substrates for enantioselective reactions of this class. Not only $\mathrm{N}$ nucleophiles, but also electron-rich aromatic derivatives, as well as sulphur nucleophiles might be suitably designed.

Table 4. Effect of H-bonding functions on the enantioselective cycloisomerization/addition reactions on 1a.

(R)-C

${ }^{\text {[a] }}$ Isolated yield. ${ }^{[b]}$ Determined by chiral HPLC.

\section{Conclusion}

In summary, we have investigated the use of planar chiral [4.3]-paracyclophane $\mathbf{I}$ and [3.3]paracyclophane II as chiral counterions in asymmetric organometallic catalysis. We have targeted the catalytic process in Scheme 1, which converts 2-alkynyl-enones into highly substituted furans through a domino cycloisomerization/nucleophilic addition reaction, based on the hypothesis that the chiral counterion strategy might be especially suited here. We have demonstrated that the silver phosphate derived from Ia efficiently promotes these domino reactions with indoles as $C$-nucleophiles. The catalyst affords the desired 3-indolyl-substituted bicyclic furans with enantiomeric excesses in the $82-86 \%$ range (4 examples). In terms of enantiomeric excess, the catalyst compares favorably with both silver phosphates derived from TRIP and $\left(\mathrm{PPh}_{3}\right) \mathrm{Au}^{+}$ phosphates.

This domino sequence has been extended then to $\mathrm{N}$-nucleophiles such as anilines and sulfonamides, in 
racemic and enantioselective versions. This study has highlighted the beneficial effect on the enantioselectivity of the presence of free $\mathrm{N}-\mathrm{H}$ groups in $C$-nucleophilic indoles, as well of the presence of pendant secondary amide functions in the anilines used as the nucleophilic substrates. The enhanced enantioselectivity level has been tentatively ascribed to $\mathrm{H}$-bonds between the $\mathrm{NH}$ function of these substrates and the phosphate counterion, giving a more constrained arrangement of intermediates in the key enantiodetermining step. Further studies will target extension of this concept to other series of nucleophilic substrates.

\section{Experimental Section}

\section{General Information}

All reactions were performed using flame dried flasks under argon. Dry $\mathrm{CH}_{2} \mathrm{Cl}_{2}$, cis-1,2-dichloroethylene and fluorobenzene were obtained by distillation from $\mathrm{CaH}_{2}$. Reactions were monitored by thin-layer chromatography on Merck silica gel plates (60 $\mathrm{F}_{254}$ aluminum sheets), which were rendered visible by ultraviolet light and/or spraying with potassium permanganate solution followed by heating as developing agent. All separations were performed under flash chromatography on silica gel (RediSep prepacked column, 230-400 mesh) at medium pressure (20 psi) using an automated CombiFlash Companion chromatographic system. Reagent-grade chemicals were obtained from commercial suppliers (Sigma-Aldrich, Acros Organics, and Alfa-Aesar) and were used without purification. ${ }^{1} \mathrm{H}(500.1$ or $300.2 \mathrm{MHz})$, ${ }^{13} \mathrm{C}(125.8$ or $75.5 \mathrm{MHz})$, and ${ }^{31} \mathrm{P}$ NMR Spectra $(121.5$ $\mathrm{MHz}$ ) were recorded with Bruker Avance spectrometers at 298 K. Carbon multiplicities were determined by DEPT135 experiments. Infrared spectra (IR) were recorded with a Perkin-Elmer FT-IR spectrophotometer. Optical rotations were measured using a JASCO P-1010 polarimeter and data are reported as follows: $[\alpha]_{\mathrm{D}}^{20}$, concentration $(c$ in $\mathrm{g} / 100 \mathrm{~mL}$ ) and solvent. High-resolution mass spectra (HRMS) were recorded with a Micromass LCT Premier $\mathrm{XE}$ instrument (Waters) and were determined by electrospray ionization (ESI) coupled with a time of flight analyser (TOF).

\section{Synthesis of chiral silver phosphates}

Silver phosphate $\left(\boldsymbol{R}_{\mathbf{p}}\right)$-A. $\left(R_{\mathrm{p}}\right)$-Ia $(51 \mathrm{mg}, 0.06 \mathrm{mmol})$ and silver carbonate $(8.2 \mathrm{mg}, 0.03 \mathrm{mmol}, 0.5$ equiv.) were reacted in $\mathrm{CH}_{2} \mathrm{Cl}_{2} / \mathrm{H}_{2} \mathrm{O} 1: 1(2 \mathrm{~mL})$ at $40{ }^{\circ} \mathrm{C}$ for $20 \mathrm{~h}$ under argon in the dark. Then the reaction medium was concentrated under reduced pressure to provide the corresponding silver phosphate $\left(R_{\mathrm{p}}\right)$-A in quantitative yield ${ }^{1} \mathrm{H}$ NMR $\left(300.2 \mathrm{MHz}, \mathrm{CDCl}_{3}\right), \delta(\mathrm{ppm})=7.78(\mathrm{~s}, 6 \mathrm{H})$, $7.68(\mathrm{~d}, J=7.8 \mathrm{~Hz}, 8 \mathrm{H}), 7.54(\mathrm{~s}, 2 \mathrm{H}), 7.37(\mathrm{t}, J=7.8 \mathrm{~Hz}$, $8 \mathrm{H}), 7.26(\mathrm{~d}, J=7.8 \mathrm{~Hz}, 4 \mathrm{H}), 6.97(\mathrm{dd}, J=8.3$ and $1.9 \mathrm{~Hz}$, $2 \mathrm{H}), 6.93(\mathrm{~d}, J=8.3 \mathrm{~Hz}, 2 \mathrm{H}), 6.84-6.76(\mathrm{~m}, 4 \mathrm{H}), 6.22(\mathrm{dd}$, $J=8.3$ and $1.9 \mathrm{~Hz}, 2 \mathrm{H}) ;{ }^{13} \mathrm{C} \mathrm{NMR}\left(125.8 \mathrm{MHz}, \mathrm{CDCl}_{3}\right), \delta$ $(\mathrm{ppm})=151.9,150.1,149.7,141.8,140.6,139.2,135.5$, $132.2,131.9,129.1,128.9,128.3,128.2,127.8,127.6$, $127.5,127.2,125.7,121.1,116.6 ;{ }^{31} \mathrm{P}$ NMR $(121.5 \mathrm{MHz}$, $\left.\mathrm{CDCl}_{3}\right), \delta(\mathrm{ppm})=-1.2$; IR: $v_{\max }=3058,3034,2961,2925$, $1660,1593,1577,1499,1450,1413,1378,1262,1228$, $1215, \quad 1072,915,877,862 \mathrm{~cm}^{-1}$; HR-MS (ESI): $m / z=853.2531$, calcd. for $\mathrm{C}_{60} \mathrm{H}_{38} \mathrm{O}_{4} \mathrm{P}[\mathrm{M}-\mathrm{Ag}]^{-}:$853.2508; $[\alpha]_{D}^{20}=-79\left(\mathrm{c}=0.5, \mathrm{CHCl}_{3}\right)$.

Silver phosphate $(\boldsymbol{R})$-C is prepared following the above procedure and NMR data are consistent with those previously described in the literature. ${ }^{[5 a, 31]}$ NMR $(500.2$ $\left.\mathrm{MHz}, \mathrm{CDCl}_{3}\right), \delta(\mathrm{ppm})=7.86(\mathrm{~d}, J=8.2 \mathrm{~Hz}, 2 \mathrm{H}), 7.83(\mathrm{~s}$,
$2 \mathrm{H}), 7.45(\mathrm{t}, J=7.5 \mathrm{~Hz}, 2 \mathrm{H}), 7.35-7.28(\mathrm{~m}, 4 \mathrm{H}), 7.01(\mathrm{~s}$, $2 \mathrm{H}), 6.95(\mathrm{~s}, 2 \mathrm{H}), 2.81$ (hept, $J=6.9 \mathrm{~Hz}, 2 \mathrm{H}), 2.67$ (hept, $J$ $=6.9 \mathrm{~Hz}, 4 \mathrm{H}), 1.21(\mathrm{~d}, J=6.9 \mathrm{~Hz}, 6 \mathrm{H}), 1.16-1.14(\mathrm{~m}, 24$ $\mathrm{H}), 0.93(\mathrm{~d}, J=6.9 \mathrm{~Hz}, 6 \mathrm{H})$.

\section{General procedure for the silver phosphate- catalyzed cycloisomerization/cddition reactions.}

A Schlenk tube was charged with 2-(1-alkynyl)-2-alken-1one $(0.1 \mathrm{mmol})$, nucleophile $(0.1 \mathrm{mmol})$ and catalyst $(10$ mol\%) The reaction medium was purged by evacuating to $6.10^{-2} \mathrm{mmHg}$ and flushing with argon $(3 \mathrm{x})$. Then the desired solvent was added and the reaction mixture was stirred at room temperature for $18 \mathrm{~h}$ under argon in the dark. The reaction mixture was filtered on silica gel and purified by flash column chromatography to afford the desired product.

\section{3-(2-Phenyl-4,5,6,7-tetrahydrobenzofuran-4-yl)-1H- indole (3a).}

Following the general procedure with $\mathrm{AgPF}_{6}$, the crude residue was purified by flash chromatography (eluent: $n$ heptane $100 \%$ to $n$-heptane/EtOAc 80:20) to afford compound 3a in $88 \%$ yield $(27.5 \mathrm{mg}) .{ }^{1} \mathrm{H}$ NMR $(500.2$ $\left.\mathrm{MHz}_{1} \mathrm{CDCl}_{3}\right), \delta(\mathrm{ppm})=7.94(\mathrm{~s}, 1 \mathrm{H}), 7.63(\mathrm{~d}, J=7.9 \mathrm{~Hz}$ $1 \mathrm{H}), 7.59(\mathrm{~d}, J=7.8 \mathrm{~Hz}, 2 \mathrm{H}), 7.38(\mathrm{~d}, J=7.9 \mathrm{~Hz}, 1 \mathrm{H})$ $7,32(\mathrm{t}, J=7.8 \mathrm{~Hz}, 2 \mathrm{H}), 7.21(\mathrm{t}, J=7.9 \mathrm{~Hz}, 1 \mathrm{H}), 7.18(\mathrm{t}, J$ $=7.8 \mathrm{~Hz}, 1 \mathrm{H}), 7.12(\mathrm{t}, J=7.8 \mathrm{~Hz}, 1 \mathrm{H}), 6.89(\mathrm{~d}, J=2.4 \mathrm{~Hz}$ $1 \mathrm{H}), 6.45(\mathrm{~s}, 1 \mathrm{H}), 4.26(\mathrm{dd}, J=5.8,5.8 \mathrm{~Hz}, 1 \mathrm{H}), 2.81-2.73$ $(\mathrm{m}, 2 \mathrm{H}), 2.20-2.14(\mathrm{~m}, 1 \mathrm{H}), 2.01-1.94(\mathrm{~m}, 2 \mathrm{H}), 1.90-1.83$ $(\mathrm{m}, 1 \mathrm{H}) ;{ }^{13} \mathrm{C}$ NMR $\left(75.5 \mathrm{MHz}, \mathrm{CDCl}_{3}\right), \delta(\mathrm{ppm})=151.8$, $151.4,136.8,131.3,128.7,126.8,126.7,123.4,122.2$, 122.1, 120.4, 119.41, 119.36, 111.4, 106.2, 31.3, 31.1, 23.6, 21.3; HR-MS (ESI): $m / z=314.1551$, calcd. for $\mathrm{C}_{22} \mathrm{H}_{20} \mathrm{NO}$ $[\mathrm{M}+\mathrm{H}]^{+}: 314.1545$.

Following the general procedure with $\left(R_{p}\right)-\mathbf{A}$, the compound 3a was obtained in $83 \%$ yield $(26.0 \mathrm{mg}$ ) and $86 \%$ ee, determined by chiral HPLC [CHIRALPAK® IA column, eluent: $i$-PrOH $/ n$-heptane $5: 95,1 \mathrm{~mL}^{-m_{i n}{ }^{-1}}$ (detection at $290 \mathrm{~nm}$ )], retention times: $15.9 \mathrm{~min}$ (major) and $20.2 \mathrm{~min}$ (minor). $[\alpha]_{\mathrm{D}}^{20}:-29.6\left(c=0.5, \mathrm{CHCl}_{3}\right)$.

Following the general procedure with $(R)-\mathbf{C}$, the compound 3a was obtained in $83 \%$ yield $(26.0 \mathrm{mg})$ and $67 \%$ ee, determined by chiral HPLC, retention times: 15.6 min (minor) and $19.8 \mathrm{~min}$ (major). $[\alpha]_{\mathrm{D}}^{20}:+27.6(c=0.5$, $\left.\mathrm{CHCl}_{3}\right)$.

\section{5-Methyl-3-(2-phenyl-4,5,6,7-tetrahydrobenzofuran-4-} yl)-1H-indole (3b).

Following the general procedure with $\mathrm{AgPF}_{6}$, the crude residue was purified by flash chromatography (eluent: $n$ heptane $100 \%$ to $n$-heptane/EtOAc 80:20) to afford compound $\mathbf{3 b}$ in $42 \%$ yield $(13.7 \mathrm{mg}) .{ }^{1} \mathrm{H}$ NMR $(300.2$ $\left.\mathrm{MHz}_{1} \mathrm{CDCl}_{3}\right), \delta(\mathrm{ppm})=7.81(\mathrm{~s}, 1 \mathrm{H}), 7.58(\mathrm{~d}, J=7.8 \mathrm{~Hz}$, $2 \mathrm{H}), 7.40(\mathrm{~s}, 1 \mathrm{H}), 7,31(\mathrm{t}, J=7.8 \mathrm{~Hz}, 2 \mathrm{H}), 7.25(\mathrm{~d}, J=7.8$ $\mathrm{Hz}, 1 \mathrm{H}), 7.16(\mathrm{t}, J=7.8 \mathrm{~Hz}, 1 \mathrm{H}), 7.02(\mathrm{~d}, J=7.8 \mathrm{~Hz}, 1 \mathrm{H})$ $6.79(\mathrm{~d}, J=2.3 \mathrm{~Hz}, 1 \mathrm{H}), 6.43(\mathrm{~s}, 1 \mathrm{H}), 4.21(\mathrm{t}, J=5.5 \mathrm{~Hz}$ $1 \mathrm{H}), 2.76-2.72(\mathrm{~m}, 2 \mathrm{H}), 2.45(\mathrm{~s}, 3 \mathrm{H}), 2.18-2.09(\mathrm{~m}, 1 \mathrm{H})$ $1.97-1.88(\mathrm{~m}, 2 \mathrm{H}), 1.85-1.79(\mathrm{~m}, 1 \mathrm{H}) ;{ }^{13} \mathrm{C} \mathrm{NMR}(75.5$ $\left.\mathrm{MHz}, \mathrm{CDCl}_{3}\right), \delta(\mathrm{ppm})=151.8,151.4,135.0,131.5,128.7$, $127.1,126.7,123.7,123.4,122.4,122.3,119.9,118.9$, 113.9, 111.0, 106.2, 31.3, 31.0, 23.6, 21.7, 21.2; IR: $v_{\max }=$ $3418,2935,2856,1602,1550,1486,1447,1180,1092$, 909, 795, 760, 733, 692 $\mathrm{cm}^{-1}$; HR-MS (ESI): $m / z=328.1700$, calcd. for $\mathrm{C}_{23} \mathrm{H}_{22} \mathrm{NO}\left[\mathrm{M}+\mathrm{H}^{+}:\right.$: 328.1701.

Following the general procedure with $\left(R_{p}\right)-\mathbf{A}$, the compound $\mathbf{3 b}$ was obtained in $95 \%$ yield $(31.1 \mathrm{mg}$ ) and $86 \%$ ee, determined by chiral HPLC [CHIRALPAK® IA column, eluent: $i$-PrOH $/ n$-heptane 10:90, $1 \mathrm{~mL} \cdot \mathrm{min}^{-1}$ (detection at $254 \mathrm{~nm}$ )], retention times: $7.7 \mathrm{~min}$ (major) and $10.5 \mathrm{~min}$ (minor).

Following the general procedure with $(R)-\mathbf{C}$, the compound $\mathbf{3 b}$ was obtained in $93 \%$ (30.4 mg) yield and $64 \%$ ee, determined by chiral HPLC, retention times: 6.9 min (minor) and $8.8 \mathrm{~min}$ (major). 
5-Fluoro-3-(2-phenyl-4,5,6,7-tetrahydrobenzofuran-4yl)-1H-indole (3c).

Following the general procedure with $\mathrm{AgPF}_{6}$, the crude residue was purified by flash chromatography (eluent: $n$ heptane $100 \%$ to $n$-heptane/EtOAc 80:20) to afford compound $3 \mathrm{c}$ in $33 \%$ yield $(10.9 \mathrm{mg}) .{ }^{1} \mathrm{H}$ NMR $(500.2$ $\left.\mathrm{MHz}, \mathrm{CDCl}_{3}\right), \delta(\mathrm{ppm})=7.94(\mathrm{~s}, 1 \mathrm{H}), 7.60(\mathrm{~d}, J=7.7 \mathrm{~Hz}$, $2 \mathrm{H}), 7.33(\mathrm{t}, J=7.7 \mathrm{~Hz}, 2 \mathrm{H}), 7.30-7.23(\mathrm{~m}, 2 \mathrm{H}), 7.19(\mathrm{t}, J$ $=7.7 \mathrm{~Hz}, 1 \mathrm{H}), 6.97-6.93(\mathrm{~m}, 2 \mathrm{H}), 6.42(\mathrm{~s}, 1 \mathrm{H}), 4.18(\mathrm{dd}, J$ $=6.2,5.2 \mathrm{~Hz}, 1 \mathrm{H}), 2.81-2.73(\mathrm{~m}, 2 \mathrm{H}), 2.17-2.13(\mathrm{~m}, 1 \mathrm{H})$, $1.99-1.85(\mathrm{~m}, 3 \mathrm{H})$.

Following the general procedure with $\left(R_{p}\right)-\mathbf{A}$, the compound 3c was obtained in $97 \%$ yield $(32.1 \mathrm{mg}$ ) and $82 \%$ ee, determined by chiral HPLC [CHIRALPAK ® IA column, eluent: $i$-PrOH $/ n$-heptane 10:90, $1 \mathrm{~mL}^{-\mathrm{min}^{-1}}$ (detection at $254 \mathrm{~nm}$ )], retention times: $8.7 \mathrm{~min}$ (major) and 9.9 min (minor).

Following the general procedure with $(R)-\mathbf{C}$, the compound 3c was obtained in $95 \%$ yield $(31.5 \mathrm{mg})$ and $73 \%$ ee, determined by chiral HPLC, retention times: 7.7 min (minor) and 8.6 min (major).

\section{5-Fluoro-3-(2-phenyl-4,5,6,7-tetrahydrobenzofuran-4- yl)-1H-indole (3d).}

Following the general procedure with $\mathrm{AgPF}_{6}$, the crude residue was purified by flash chromatography (eluent: $n$ heptane $100 \%$ to $n$-heptane/EtOAc 80:20) to afford compound 3d in $37 \%$ yield $(12.7 \mathrm{mg})$. ${ }^{1} \mathrm{H}$ NMR $(500.2$ $\left.\mathrm{MHz}, \mathrm{CDCl}_{3}\right), \delta(\mathrm{ppm})=7.84(\mathrm{~s}, 1 \mathrm{H}), 7.60(\mathrm{~d}, J=7.8 \mathrm{~Hz}$, $2 \mathrm{H}), 7.33(\mathrm{t}, J=7.8 \mathrm{~Hz}, 2 \mathrm{H}), 7.27(\mathrm{~d}, J=8.5 \mathrm{~Hz}, 1 \mathrm{H}), 7.19$ $(\mathrm{t}, J=7.8 \mathrm{~Hz}, 1 \mathrm{H}), 7,06(\mathrm{~s}, 1 \mathrm{H}), 6.89-6.86(\mathrm{~m}, 2 \mathrm{H}), 6.46(\mathrm{~s}$, $1 \mathrm{H}), 4.24-4.20(\mathrm{~m}, 1 \mathrm{H}), 3.86(\mathrm{~s}, 3 \mathrm{H}), 2.84-2.70(\mathrm{~m}, 2 \mathrm{H})$, 2.20-2.12 (m, 1H), 1.96-1.87 (m, 3H).

Following the general procedure with $\left(R_{p}\right)-\mathbf{A}$, the compound 3d was obtained in $79 \%$ yield (27.1 mg) and $84 \%$ ee, determined by chiral HPLC [CHIRALPAK@ IA column, eluent: $i$-PrOH $/ n$-heptane $10: 90,1 \mathrm{~mL}^{-\mathrm{min}^{-1}}$ (detection at $254 \mathrm{~nm}$ )], retention times: $12.2 \mathrm{~min}$ (major) and $16.4 \mathrm{~min}$ (minor).

Following the general procedure with $(R)-\mathbf{C}$, the compound 3d was obtained in $67 \%$ yield $(23.0 \mathrm{mg})$ and $63 \%$ ee, determined by chiral HPLC, retention times: 10.5 min (minor) and 12.9 min (major).

\section{1-Methyl-3-(2-phenyl-4,5,6,7-tetrahydrobenzofuran-4- yl)-1H-indole (3e).}

Following the general procedure with $\mathrm{AgPF}_{6}$, the crude residue was purified by flash chromatography (eluent: $n$ heptane $100 \%$ to $n$-heptane/EtOAc 80:20) to afford compound $3 \mathbf{e}$ in $84 \%$ yield $(27.5 \mathrm{mg}) .{ }^{1} \mathrm{H}$ NMR $(500.2$ $\left.\mathrm{MHz}, \mathrm{CDCl}_{3}\right), \delta(\mathrm{ppm})=7.64-7.60(\mathrm{~m}, 3 \mathrm{H}), 7.35-7.31(\mathrm{~m}$, $3 \mathrm{H}), 7.24-7.26(\mathrm{~m}, 2 \mathrm{H}), 7.12(\mathrm{~m}, 1 \mathrm{H}), 6.74(\mathrm{~s}, 1 \mathrm{H}), 6.47(\mathrm{~s}$, $1 \mathrm{H}), 4.27(\mathrm{dd}, J=5.5,5.5 \mathrm{~Hz}, 1 \mathrm{H}), 3.73(\mathrm{~s}, 3 \mathrm{H}), 2.80-2.76$ (m, 2H), 2.20-2.14 (m, 1H), 2.02-1.94 (m, 2H), 1.90-1.84 $(\mathrm{m}, 1 \mathrm{H}) ;{ }^{13} \mathrm{C} \mathrm{NMR}\left(75.5 \mathrm{MHz}, \mathrm{CDCl}_{3}\right), \delta(\mathrm{ppm})=151.8$, $151.3,137.4,131.6,128.9,128.7,127.2$, 127.1, 126.7, 123.4, 122.4, 121.6, 119.4, 118.8, 109.4, 106.3, 32.8, 31.5, 30.9, 23.6, 21.2; IR: $v_{\max }=3055,2934,2855,1678,1602$, 1472, 1326, 1234, 909, 760, 737, $692 \mathrm{~cm}^{-1}$; HR-MS (ESI): $m / z=328.1701$, calcd. for $\mathrm{C}_{23} \mathrm{H}_{22} \mathrm{NO}[\mathrm{M}+\mathrm{H}]^{+}: 328.1690$.

Following the general procedure with $\left(R_{p}\right)-\mathbf{A}$, the compound $3 \mathbf{e}$ was obtained in $27 \%$ yield $(8.8 \mathrm{mg})$ and $37 \%$ ee, determined by chiral HPLC [CHIRALPAK® IC column, eluent: $i$-PrOH $/ n$-heptane $5: 95,1 \mathrm{~mL}^{-\mathrm{min}^{-1}}$ (detection at $254 \mathrm{~nm}$ )], retention times: $4.5 \mathrm{~min}$ (major) and 4.9 min (minor).

Following the general procedure with $(R)-\mathbf{C}$, the compound 3e was obtained in $24 \%$ yield $(7.8 \mathrm{mg})$ and $37 \%$ ee, determined by chiral HPLC, retention times: $4.5 \mathrm{~min}$ (minor) and 4.9 min (major).

\section{3-(2-(4-Methoxyphenyl)-4,5,6,7-tetrahydrobenzofuran- 4-yl)-1H-indole (3f). ${ }^{[18}$}

Following the general procedure with $\mathrm{AgPF}_{6}$, the crude residue was purified by flash chromatography (eluent: $n$ heptane $100 \%$ to $n$-heptane/EtOAc 80:20) to afford compound $3 f$ in $55 \%$ yield (18.8 mg). ${ }^{1} \mathrm{H}$ NMR (500.2
$\left.\mathrm{MHz}, \mathrm{CDCl}_{3}\right), \delta(\mathrm{ppm})=7.93(\mathrm{~s}, 1 \mathrm{H}), 7.63(\mathrm{~d}, J=7.9 \mathrm{~Hz}$ $1 \mathrm{H}), 7.52(\mathrm{~d}, J=8.6 \mathrm{~Hz}, 2 \mathrm{H}), 7.38(\mathrm{~d}, J=7.9 \mathrm{~Hz}, 1 \mathrm{H})$ $7.21(\mathrm{t}, J=7.9 \mathrm{~Hz}, 1 \mathrm{H}), 7.12(\mathrm{t}, J=7.9 \mathrm{~Hz}, 1 \mathrm{H}), 6.89(\mathrm{~s}$, $1 \mathrm{H}), 6.87(\mathrm{~d}, J=8.6 \mathrm{~Hz}, 2 \mathrm{H}), 6.31(\mathrm{~s}, 1 \mathrm{H}), 4.25(\mathrm{dd}, J=$ 6.0, 5.7 Hz, 1H), 3.81 (s, 3H), 2.80-2.71 (m, 2H), 2.19$2.13(\mathrm{~m}, 1 \mathrm{H}), 2.00-1.93(\mathrm{~m}, 2 \mathrm{H}), 1.89-1.82(\mathrm{~m}, 1 \mathrm{H})$.

Following the general procedure with $\left(R_{p}\right)-\mathbf{A}$, the compound 3f was obtained in $67 \%$ yield $(23.0 \mathrm{mg})$ and 74\% ee, determined by chiral HPLC [CHIRALPAK® IA column, eluent: $i$-PrOH $/ n$-heptane $5: 95,1 \mathrm{~mL}^{-\mathrm{min}^{-1}}$ (detection at $290 \mathrm{~nm}$ )], retention times: $36.3 \mathrm{~min}$ (major) and 38.4 min (minor).

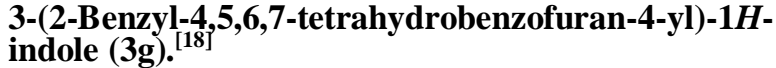

Following the general procedure with $\mathrm{AgPF}_{6}$, the crude residue was purified by flash chromatography (eluent: $n$ heptane $100 \%$ to $n$-heptane/EtOAc 80:20) to afford compound $\mathbf{3 g}$ in $27 \%$ yield $(8.8 \mathrm{mg})$. ${ }^{1} \mathrm{H}$ NMR $(500.2 \mathrm{MHz}$, $\left.\mathrm{CDCl}_{3}\right), \delta(\mathrm{ppm})=7.88(\mathrm{~s}, 1 \mathrm{H}), 7.57(\mathrm{~d}, J=8.0 \mathrm{~Hz}, 1 \mathrm{H})$, $7.35(\mathrm{~d}, J=8.3 \mathrm{~Hz}, 1 \mathrm{H}), 7.29-7.16(\mathrm{~m}, 6 \mathrm{H}), 7.09(\mathrm{t}, J=8.0$ $\mathrm{Hz}, 1 \mathrm{H}), 6.83(\mathrm{~s}, 1 \mathrm{H}), 5.79(\mathrm{~s}, 1 \mathrm{H}), 4.16(\mathrm{t}, J=5.8 \mathrm{~Hz}, 1 \mathrm{H})$, $3.90(\mathrm{~s}, 2 \mathrm{H}), 2.68-2.58(\mathrm{~m}, 2 \mathrm{H}), 2.13-2.08(\mathrm{~m}, 1 \mathrm{H}), 1.93-$ $1.86(\mathrm{~m}, 2 \mathrm{H}), 1.82-1.75(\mathrm{~m}, 1 \mathrm{H})$.

Following the general procedure with $\left(R_{p}\right)-\mathbf{A}$, the compound $3 \mathrm{~g}$ was obtained in $47 \%$ yield $(15.4 \mathrm{mg})$ and $60 \%$ ee, determined by chiral HPLC [CHIRALPAK@ IA column, eluent: $i$-PrOH $/ n$-heptane $5: 95,1 \mathrm{~mL} \cdot \mathrm{min}^{-1}$ (detection at $290 \mathrm{~nm}$ )], retention times: $12.5 \mathrm{~min}$ (major) and 16.9 min (minor).

\section{$N$-Phenyl-2-phenyl-4,5,6,7-tetrahydrobenzofuran-4- amine (4a).}

Following the general procedure with $\mathrm{AgPF}_{6}$, the crude residue was purified by flash chromatography (eluent: $n$ heptane $100 \%$ to $n$-heptane/EtOAc 80:20) to afford compound 4a in $89 \%$ yield (25.7 mg). ${ }^{1} \mathrm{H}$ NMR $(500.2$ $\left.\mathrm{MHz} \mathrm{CDCl}_{3}\right) \delta(\mathrm{ppm})=7.61(\mathrm{~d}, J=7.9 \mathrm{~Hz}, 2 \mathrm{H}), 7.35(\mathrm{t}, J$ $=7.9 \mathrm{~Hz}, 2 \mathrm{H}), 7.23(\mathrm{t}, J=7.9 \mathrm{~Hz}, 1 \mathrm{H}), 7.22(\mathrm{t}, J=7.9 \mathrm{~Hz}$, $2 \mathrm{H}), 6.74(\mathrm{t}, J=7.9 \mathrm{~Hz}, 1 \mathrm{H}), 6.71(\mathrm{~d}, J=7.9 \mathrm{~Hz}, 2 \mathrm{H})$ $6.60(\mathrm{~s}, 1 \mathrm{H}), 4.59(\mathrm{~s}, 1 \mathrm{H}), 3.84(\mathrm{~s}, 1 \mathrm{H}), 2.77-2.64(\mathrm{~m}, 2 \mathrm{H})$ $2.02-1.97(\mathrm{~m}, 2 \mathrm{H}), 1.90-1.82(\mathrm{~m}, 2 \mathrm{H}) ;{ }^{13} \mathrm{C}$ NMR $(75.5$ $\left.\mathrm{MHz}_{1} \mathrm{CDCl}_{3}\right) \delta(\mathrm{ppm})=152.5,152.3,147.3,131.2,129.5$ $128.8,127.1,123.5,121.6,117.5,113.3,105.0,47.0,29.4$ 23.3, 19.8; IR: $v_{\max }=3406,3051,2936,2850,1600,1502$, 1312, 758, 748, $691 \mathrm{~cm}^{-1}$; HR-MS (APPI): $m / z=289.1463$, calcd. for $\mathrm{C}_{20} \mathrm{H}_{19} \mathrm{NO}[\mathrm{M}]^{+}:$: 286.1466.

Following the general procedure with $\left(R_{p}\right)-\mathbf{A}$, the compound 4 a was obtained in $84 \%$ yield $(24.3 \mathrm{mg})$ and $1 \%$ ee, determined by chiral HPLC [CHIRALPAK ${ }^{\circledR}$ IB column, eluent: $i$-PrOH $/ n$-heptane 02:98, 1 mL.min ${ }^{-1}$ (detection at $254 \mathrm{~nm}$ )], retention times: $8.9 \mathrm{~min}$ (minor) and 11.4 min (major).

Following the general procedure with $(R)-\mathbf{C}$, the compound 4 a was obtained in $75 \%$ yield $(21.7 \mathrm{mg})$ and $11 \%$ ee, determined by chiral HPLC, retention times: 9.0 min (minor) and 11.4 min (major).

\section{tert-Butyl-(2-phenyl-4,5,6,7-tetrahydrobenzofuran-4-} yl)carbamate (4b).

Following the general procedure with $\mathrm{AgPF}_{6}$, the crude residue was purified by flash chromatography (eluent: $n$ heptane $100 \%$ to $n$-heptane/EtOAc 80:20) to afford compound $\mathbf{4 b}$ in $87 \%$ yield $(27.2 \mathrm{mg}) .{ }^{1} \mathrm{H}$ NMR $(500.2$ $\left.\mathrm{MHz}, \mathrm{CDCl}_{3}\right), \delta(\mathrm{ppm})=7.61(\mathrm{~d}, J=7.9 \mathrm{~Hz}, 2 \mathrm{H}), 7.35(\mathrm{t}$ $J=7.9 \mathrm{~Hz}, 2 \mathrm{H}), 7.22(\mathrm{t}, \mathrm{J}=7.9 \mathrm{~Hz}, 1 \mathrm{H}), 6.59(\mathrm{~s}, 1 \mathrm{H})$, $4.75-4.67(\mathrm{~m}, 2 \mathrm{H}), 2.70-2.58(\mathrm{~m}, 2 \mathrm{H}), 2.04-1.98(\mathrm{~m}, 1 \mathrm{H})$, $1.95-1.82(\mathrm{~m}, 2 \mathrm{H}), 1.72-1.67(\mathrm{~m}, 1 \mathrm{H}), 1.49(\mathrm{~s}, 9 \mathrm{H}) ;{ }^{13} \mathrm{C}$ NMR $\left(75.5 \mathrm{MHz}, \mathrm{CDCl}_{3}\right) \delta(\mathrm{ppm})=155.5,152.6,152.2$, $131.1,128.7,127.1,123.5,120.7,104.8,79.5,44.7,30.6$, 28.6, 23.1, 20.0; IR: $v_{\max }=3334,2975,2931,2864,1692$ $1604,1487,1365,1246,1168,1058,919,759,692 \mathrm{~cm}^{-1}$; HR-MS (ESI): $m / z=314.1766$, calcd. for $\mathrm{C}_{19} \mathrm{H}_{24} \mathrm{NO}_{3}$ $[\mathrm{M}+\mathrm{H}]^{+}: 314.1756$.

Following the general procedure with $\left(R_{p}\right)-\mathbf{A}$, the compound $\mathbf{4 b}$ was obtained in $18 \%$ yield $(5.6 \mathrm{mg})$ and $46 \%$ ee, determined by chiral HPLC [CHIRALPAK® IA 
column, eluent: $i$-PrOH$/ n$-heptane $10: 90,1$ mL.min ${ }^{-1}$ (detection at $254 \mathrm{~nm}$ )], retention times: 4.9 min (major) and $6.3 \mathrm{~min}$ (minor).

Following the general procedure with $(R)-\mathbf{C}$, the compound $\mathbf{4 b}$ was obtained in $15 \%$ yield $(4.7 \mathrm{mg})$ and $50 \%$ ee, determined by chiral HPLC, retention times: 4.9 min (minor) and $6.3 \mathrm{~min}$ (major).

\section{Benzyl-(2-phenyl-4,5,6,7-tetrahydrobenzofuran-4- yl)carbamate $(4 \mathrm{c})$}

Following the general procedure with $\mathrm{AgPF}_{6}$, the crude residue was purified by flash chromatography (eluent: $n$ heptane $100 \%$ to $n$-heptane/EtOAc 80:20) to afford compound $4 \mathbf{c}$ in $76 \%$ yield $(26.4 \mathrm{mg}) .{ }^{1} \mathrm{H}$ NMR $(300.2$ $\left.\mathrm{MHz}, \mathrm{CDCl}_{3}\right) \delta(\mathrm{ppm})=7.63(\mathrm{~d}, J=7.8 \mathrm{~Hz}, 2 \mathrm{H}), 7.43-$ $7.34(\mathrm{~m}, 7 \mathrm{H}), 7.25(\mathrm{t}, J=7.8 \mathrm{~Hz}, 1 \mathrm{H}), 6.61(\mathrm{~s}, 1 \mathrm{H}), 5.19(\mathrm{~d}$, $J=12.6 \mathrm{~Hz}, 1 \mathrm{H}), 5.18(\mathrm{~d}, J=12.6 \mathrm{~Hz}, 1 \mathrm{H}), 4.97(\mathrm{bd}, J=$ $7.6 \mathrm{~Hz}$ and $1 \mathrm{H}), 4.82$ (bdt, $J=7.6,5.3 \mathrm{~Hz}, 1 \mathrm{H}), 2.77-2.59$ $(\mathrm{m}, 2 \mathrm{H}), 2.13-2.00(\mathrm{~m}, 1 \mathrm{H}), 1.98-1.88(\mathrm{~m}, 2 \mathrm{H}), 1.81-1.72$ $(\mathrm{m}, 1 \mathrm{H}) ;{ }^{13} \mathrm{C}$ NMR $\left(75.5 \mathrm{MHz}, \mathrm{CDCl}_{3}\right) \delta(\mathrm{ppm})=156.0$, $152.7,152.3,136.7,131.0,128.84,1228.78,128.7,128.6$, $128.3,127.2,123.5,120.3,104.7,66.9,45.3,30.6,23.1$, 20.0; IR: $v_{\max }=3412,3317,3062,3033,2943,2845,1695$, $1604,1522,1454,1345,1225,1058,1022,965,950 \mathrm{~cm}^{-1}$; HR-MS (ESI): $m / z=348.1602$, calcd. for $\mathrm{C}_{22} \mathrm{H}_{22} \mathrm{NO}_{3}$ $[\mathrm{M}+\mathrm{H}]^{+}: 348.1600$.

Following the general procedure with $\left(R_{p}\right)-\mathbf{A}$, the compound $4 \mathbf{c}$ was obtained in $25 \%$ yield $(8.7 \mathrm{mg})$ and $43 \%$ ee, determined by chiral HPLC [CHIRALPAK ${ }^{\circledR}$ IB column, eluent: $i$-PrOH $/ n$-heptane $2: 98,1 \mathrm{~mL}^{-\mathrm{min}^{-1}}$ (detection at $254 \mathrm{~nm}$ )], retention times: 12.2 min (major) and $14.8 \mathrm{~min}$ (minor).

Following the general procedure with $(R)-\mathbf{C}$, the compound $4 \mathbf{c}$ was obtained in $24 \%$ yield $(8.3 \mathrm{mg})$ and $52 \%$ ee, determined by chiral HPLC, retention times: $12.1 \mathrm{~min}$ (minor) and $14.6 \mathrm{~min}$ (major).

\section{4-Methyl- $N$-(2-phenyl-4,5,6,7-tetrahydrobenzofuran-4- yl)benzenesulfonamide (4d).}

Following the general procedure with $\mathrm{AgPF}_{6}$, the crude residue was purified by flash chromatography (eluent: $n$ heptane $100 \%$ to $n$-heptane/EtOAc 80:20) to afford compound 4d in $94 \%$ yield $(33.2 \mathrm{mg}) .{ }^{1} \mathrm{H}$ NMR $(500.2$ $\left.\mathrm{MHz} \mathrm{CDCl}_{3}\right) \delta(\mathrm{ppm})=7.84(\mathrm{~d}, J=8.1 \mathrm{~Hz}, 2 \mathrm{H}), 7.47(\mathrm{~d}$, $J=7.4 \mathrm{~Hz}, 2 \mathrm{H}), 7.36(\mathrm{~d}, J=8.1 \mathrm{~Hz}, 2 \mathrm{H}), 7.33(\mathrm{t}, J=7.4$ $\mathrm{Hz}, 2 \mathrm{H}), 7.22(\mathrm{t}, J=7.4 \mathrm{~Hz}, 1 \mathrm{H}), 5.87(\mathrm{~s}, 1 \mathrm{H}), 4.68(\mathrm{~d}, J=$ $8.4 \mathrm{~Hz}), 4.38-4.35(\mathrm{~m}, 1 \mathrm{H}), 2.82(\mathrm{ddd}, J=16.5,5.5,4.8 \mathrm{~Hz}$, $1 \mathrm{H}), 2.54(\mathrm{ddd}, J=16.5,6.0,6.0 \mathrm{~Hz}, 1 \mathrm{H}), 2.48(\mathrm{~s}, 3 \mathrm{H})$, $1.91-1.72(\mathrm{~m}, 4 \mathrm{H}) ;{ }^{13} \mathrm{C}$ NMR $\left(75.5 \mathrm{MHz}, \mathrm{CDCl}_{3}\right) \delta(\mathrm{ppm})$ $=152.7,152.6,143.6,138.6,130.8,130.0,128.7,127.4$, 127.3, 123.5, 119.7, 104.2, 47.8, 31.4, 22.9, 21.7, 19.7; IR: $v_{\max }=3275,2955,2857,1599,1447,1326,1155,1070$, $814,759,660 \mathrm{~cm}^{-1}$; HR-MS (ESI): $m / z=431.1401$, calcd. for $\mathrm{C}_{23} \mathrm{H}_{24} \mathrm{~N}_{2} \mathrm{O}_{3} \mathrm{SNa}\left[\mathrm{M}+\mathrm{CH}_{3} \mathrm{CN}+\mathrm{Na}^{+}\right]^{+}$431.1405; HR-MS (ESI): $m / z=366.1165$, calcd. for $\mathrm{C}_{21} \mathrm{H}_{20} \mathrm{NO}_{3} \mathrm{~S}[\mathrm{M}-\mathrm{H}]^{-}$: 366.1164 .

Following the general procedure with $\left(R_{p}\right)$-A, the compound $4 \mathbf{d}$ was obtained in $21 \%$ yield $(7.4 \mathrm{mg}$ ) and $8 \%$ ee, determined by chiral HPLC [CHIRALPAK® IC column, eluent: $i$-PrOH $/ n$-heptane $10: 90,1 \mathrm{~mL}^{-\mathrm{min}^{-1}}$ (detection at $254 \mathrm{~nm}$ )], retention times: $28.1 \mathrm{~min}$ (minor) and 32.5 min (major).

\section{$N$-(2-((2-Phenyl-4,5,6,7-tetrahydrobenzofuran-4- yl)amino)phenyl)acetamide (4e).}

Following the general procedure with $\mathrm{AgPF}_{6}$, the crude residue was purified by flash chromatography (eluent: $n$ heptane $100 \%$ to $n$-heptane/EtOAc $50: 50$ ) to afford compound $4 \mathrm{e}$ in $90 \%$ yield $(31.2 \mathrm{mg}){ }^{1} \mathrm{H}$ NMR $(500.2$ MHz, DMSO $), \delta(\mathrm{ppm})=9.13(\mathrm{~s}, 1 \mathrm{H}), 7.63(\mathrm{~d}, J=7.8 \mathrm{~Hz}$, $2 \mathrm{H}), 7.39(\mathrm{t}, J=7.8 \mathrm{~Hz}, 2 \mathrm{H}), 7.24(\mathrm{t}, J=7.8 \mathrm{~Hz}, 1 \mathrm{H}), 7.23$ $(\mathrm{d}, J=7.8 \mathrm{~Hz}, 1 \mathrm{H}), 7.06(\mathrm{t}, J=7.8 \mathrm{~Hz}, 1 \mathrm{H}), 6.89(\mathrm{~d}, J=$ $7.8 \mathrm{~Hz}, 1 \mathrm{H}), 6.83(\mathrm{~s}, 1 \mathrm{H}), 6.61 \mathrm{t}, J=7.8 \mathrm{~Hz}, 1 \mathrm{H}), 4.95(\mathrm{~d}$, $J=8.3 \mathrm{~Hz}, 1 \mathrm{H}), 4.61-4.57(\mathrm{~m}, 1 \mathrm{H}), 2.70-2.64(\mathrm{~m}, 2 \mathrm{H})$, $2.00(\mathrm{~s}, 3 \mathrm{H}), 1.97-1.70(\mathrm{~m}, 4 \mathrm{H}) ;{ }^{13} \mathrm{C} \mathrm{NMR}(125.8 \mathrm{MHz}$, DMSO $), \delta(\mathrm{ppm})=168.6,151.8,151.2,141.0,130.5$, $128.9,127.0,126.1,125.8,123.9,122.9,121.7,115.9$,
$111.8,106.0,45.7,28.5,23.4,22.8,19.2 ;$ IR: $v_{\max }=3269$, $3037,2941,1655,1603,1510,1451,1368,1317,1118$ 758, 734, $692 \mathrm{~cm}^{-1}$; HR-MS (ESI): $m / z=347.1759$, calcd. for $\mathrm{C}_{22} \mathrm{H}_{23} \mathrm{~N}_{2} \mathrm{O}_{2}[\mathrm{M}+\mathrm{H}]^{+}$: 347.1760.

Following the general procedure with $\left(R_{p}\right)-\mathbf{A}$, the compound $4 \mathrm{e}$ was obtained in $91 \%$ yield $(31.5 \mathrm{mg}$ ) and $8 \%$ ee, determined by chiral HPLC [CHIRALPAK ${ }^{\circledR}$ IB column, eluent: $i$-PrOH $/ n$-heptane $20: 80,1 \mathrm{~mL}^{-\mathrm{min}^{-1}}$ (detection at $254 \mathrm{~nm}$ )], retention times: 8.9 min (minor) and 22.4 min (major).

Following the general procedure with $(R)-\mathbf{C}$, the compound $4 \mathrm{e}$ was obtained in $93 \%$ yield $(32.2 \mathrm{mg})$ and 90\% ee, determined by chiral HPLC, retention times: 8.9 min (major) and 23.0 min (minor). $[\alpha]_{\mathrm{D}}^{20}:+44.4(c=0.5$, $\left.\mathrm{CHCl}_{3}\right)$.

\section{$N$-(3-((2-Phenyl-4,5,6,7-tetrahydrobenzofuran-4-}

yl)amino)phenyl)acetamide (4f).

Following the general procedure with $\mathrm{AgPF}_{6}$, the crude residue was purified by flash chromatography (eluent: $n$ heptane $100 \%$ to $n$-heptane/EtOAc 50:50) to afford compound $4 \mathbf{f}$ in $79 \%$ yield $(27.3 \mathrm{mg}) .{ }^{1} \mathrm{H}$ NMR $(500.2$ $\left.\mathrm{MHz} \mathrm{CDCl}_{3}\right), \delta(\mathrm{ppm})=7.60(\mathrm{~d}, J=7.8 \mathrm{~Hz}, 2 \mathrm{H}), 7.34(\mathrm{t}$, $J=7.8 \mathrm{~Hz}, 2 \mathrm{H}), 7.21(\mathrm{t}, J=7.8 \mathrm{~Hz}, 1 \mathrm{H}), 7.14-7.11(\mathrm{~m}$, $2 \mathrm{H}), 6.68(\mathrm{~s}, 1 \mathrm{H}), 6.59(\mathrm{~s}, 1 \mathrm{H}), 6.48(\mathrm{~s}, 1 \mathrm{H}), 4.56(\mathrm{~s}, 1 \mathrm{H})$, $2.74-2.63(\mathrm{~m}, 2 \mathrm{H}), 2.16(\mathrm{~s}, 3 \mathrm{H}), 2.01-1.96(\mathrm{~m}, 2 \mathrm{H}), 1.87-$ $1.82(\mathrm{~m}, 2 \mathrm{H})$; IR: $v_{\max }=3302,2934,2855,1664,1610$ 1551, 1486, 1283, 910, 760, 732, $692 \mathrm{~cm}^{-1}$; HR-MS (ESI): $m / z=369.1573$, calcd. for $\mathrm{C}_{22} \mathrm{H}_{22} \mathrm{~N}_{2} \mathrm{O}_{2} \mathrm{Na}[\mathrm{M}+\mathrm{Na}]^{+}$: 369.1579

Following the general procedure with $(R)-\mathbf{C}$, the compound $4 \mathbf{f}$ was obtained in $63 \%$ yield $(21.8 \mathrm{mg})$ and $21 \%$ ee, determined by chiral HPLC [CHIRALPAK® IB column, eluent: $i$-PrOH $/ n$-heptane $20: 80,1 \mathrm{~mL} \cdot \mathrm{min}^{-1}$ (detection at $254 \mathrm{~nm}$ )], retention times: 16.8 min (major) and $20.1 \mathrm{~min}$ (minor).

\section{$N$-(4-((2-Phenyl-4,5,6,7-tetrahydrobenzofuran-4- yl)amino)phenyl)acetamide (4g).}

Following the general procedure with $\mathrm{AgPF}_{6}$, the crude residue was purified by flash chromatography (eluent: $n$ heptane $100 \%$ to $n$-heptane/EtOAc 50:50) to afford compound $\mathbf{4 g}$ in $28 \%$ yield $(9.7 \mathrm{mg}) .{ }^{1} \mathrm{H}$ NMR $(500.2 \mathrm{MHz}$, $\left.\mathrm{CDCl}_{3}\right), \delta(\mathrm{ppm})=7.60(\mathrm{~d}, J=7.6 \mathrm{~Hz}, 2 \mathrm{H}), 7.34(\mathrm{t}, J=7.6$ $\mathrm{Hz}, 2 \mathrm{H}), 7.28(\mathrm{~d}, J=7.6 \mathrm{~Hz}, 2 \mathrm{H}), 7.21(\mathrm{t}, J=7.6 \mathrm{~Hz}, 1 \mathrm{H})$, $7.05-6.98(\mathrm{~m}, 1 \mathrm{H}), 6.68(\mathrm{~s}, 2 \mathrm{H}), 6.57(\mathrm{~s}, 1 \mathrm{H}), 4.53(\mathrm{~s}, 1 \mathrm{H})$, $2.75-2.63(\mathrm{~m}, 2 \mathrm{H}), 2.15(\mathrm{~s}, 3 \mathrm{H}), 1.99-1.96(\mathrm{~m}, 2 \mathrm{H}), 1.88$ $1.82(\mathrm{~m}, 2 \mathrm{H})$; IR: $v_{\max }=3301,2929,1655,1603,1550$ $1520,1311,1093,911,821,760,693 \mathrm{~cm}^{-1}$; HR-MS (ESI): $m / z=369.1571$, calcd. for $\mathrm{C}_{22} \mathrm{H}_{22} \mathrm{~N}_{2} \mathrm{O}_{2} \mathrm{Na} \quad[\mathrm{M}+\mathrm{Na}]^{+}$: 369.1579 .

Following the general procedure with $(R)-\mathbf{C}$, the compound $4 \mathrm{~g}$ was obtained in $22 \%$ yield $(7.6 \mathrm{mg})$ and $6 \%$ ee, determined by chiral HPLC [CHIRALPAK® IB column, eluent: $i$-PrOH$/ n$-heptane 20:80, $1 \mathrm{~mL} \cdot \mathrm{min}^{-1}$ (detection at $254 \mathrm{~nm}$ )], retention times: $20.4 \mathrm{~min}$ (major) and $22.0 \mathrm{~min}$ (minor).

\section{Acknowledgements}

The authors wish to thank the French National Research Agency through the programs $n^{\circ}$ ANR-11-IDEX-0003-02, CHARMMMAT ANRI1-LABX-0039 (fellowships for G.F. and Y.L.T.K.) and ANR Blanc SIMI7 - project CHIRACID $n^{\circ}$ ANR-11-BSO7-002-01 (fellowship for K.I.) and also the CNRS and ICSN for their support.

\section{References}

[1] K. Isaac, J. Stemper, V. Servajean, P. Retailleau, J. Pastor, G. Frison, K. Kaupmees, I. Leito, J.-F. 
Betzer, A. Marinetti, J. Org. Chem. 2014, 79, 9639-9646.

[2] a) J. Stemper, K. Isaac, V. Duret, P. Retailleau, A. Voituriez, J.-F. Betzer, A. Marinetti, Chem. Commun. 2013, 49, 6084-6086; b) J. Stemper, K. Isaac, J. Pastor, G. Frison, P. Retailleau, A. Voituriez, J.-F. Betzer, A. Marinetti, Adv. Synth. Catal. 2013, 355, 3613-3624; c) J. Stemper, K. Isaac, N. Ghosh, H. Lauwick, G. Le Duc, P. Retailleau, A. Voituriez, J.-F. Betzer, A. Marinetti, Adv. Synth. Catal. 2017, 359, 519-526.

[3] Other examples of paracyclophanes or ferrocenophanes embedding phosphorus functions, for catalytic uses, include trivalent phosphines (A. Feyrer, M. K. Armbruster, K. Fink, F. Breher, Chem. Eur. J. 2017, 23, 7402-7408; A. Voituriez, A. Panossian, N. Fleury-Brégeot, P. Retailleau, A. Marinetti, J. Am. Chem. Soc. 2008, 130, 1403014031) and a C1-symmetric phosphoric acid (D. Enders, M. Ludwig, G. Raabe, Chirality 2012, 24, 215-222).

[4] Z. Wu, K. Isaac, P. Retailleau, J.-F. Betzer, A. Voituriez, A. Marinetti, Chem. Eur. J. 2016, 22, 3278-3281.

[5] a) G. L. Hamilton, E. J. Kang, M. Mba, F. D. Toste, Science 2007, 317, 496-499; b) R. J. Phipps, G. L. Hamilton, F. D. Toste, Nat Chem 2012, 4, 603-614; c) M. Mahlau, B. List, Angew. Chem. Int. Ed. 2013, 52, 518-533.

[6] a) A. Parra, S. Reboredo, A. M. Martin Castro, J. Aleman, Org. Biomol. Chem. 2012, 10, 50015020; b) D. Parmar, E. Sugiono, S. Raja, M. Rueping, Chem. Rev. 2014, 114, 9047-9153.

[7] a) S. M. Inamdar, A. Konala, N. T. Patil, Chem. Commun. 2014, 50, 15124-15135; b) W. Zi, F. Dean Toste, Chem. Soc. Rev. 2016, 45, 4567-4589.

[8] a) M. Rueping, A. P. Antonchick, C. Brinkmann, Angew. Chem. Int. Ed. 2007, 46, 6903-6906; b) G. Fang, X. Bi, Chem. Soc. Rev. 2015, 44, 81248173; c) H. Pellissier, Chem. Rev. 2016, 116, 14868-14917.

[9] a) T. Yao, X. Zhang, R. C. Larock, J. Am. Chem. Soc. 2004, 126, 11164-11165; b) T. Yao, X. Zhang, R. C. Larock, J. Org. Chem. 2005, 70, 7679-7685.

[10] a) N. T. Patil, H. Wu, Y. Yamamoto, J. Org. Chem. 2005, 70, 4531-4534; b) G. Cheng, Y. Hu, Chem. Commun. 2007, 3285-3287; c) G. Cheng, Y. Hu, J. Org. Chem. 2008, 73, 4732-4735; d) W.-j. Fu, F.-j. Xu, W.-b. Guo, M. Zhu, C. Xu, Bull. Korean Chem. Soc. 2013, 34, 887-891; e) L. Huang, F. Hu, Q. Ma, Y. Hu, Tetrahedron Lett. 2013, 54, 3410-3414.

[11] a) C. H. Oh, V. R. Reddy, A. Kim, C. Y. Rhim, Tetrahedron Lett. 2006, 47, 5307-5310; b) T. He, P. Gao, S.-C. Zhao, Y.-D. Shi, X.-Y. Liu, Y.-M. Liang, Adv. Synth. Catal. 2013, 355, 365-369.

[12] a) Y. Xiao, J. Zhang, Angew. Chem. Int. Ed. 2008, 47, 1903-1906; b) L. Zhao, G. Cheng, Y. Hu, Tetrahedron Lett. 2008, 49, 7364-7367; c) Y.
Xiao, J. Zhang, Adv. Synth. Catal. 2009, 351, 617-629; d) Y. Xiao, J. Zhang, Chem. Commun. 2009, 3594-3596; e) R. Liu, J. Zhang, Chem. Eur. J. 2009, 15, 9303-9306; f) Y. Xiao, J. Zhang, Chem. Commun. 2010, 46, 752-754; g) W. Li, J. Zhang, Chem. Commun. 2010, 46, 8839-8841.

[13] a) W.-L. Chen, J. Li, Y.-H. Zhu, L.-T. Ye, W. Hu, W.-M. Mo, ARKIVOC 2011, 381-392; b) B. V. S. Reddy, V. Veerabhadra Reddy, G. Karthik, B. Jagadeesh, Tetrahedron 2015, 71, 2572-2578; c) T. He, Y. Chi, Y. Chen, Chem. Pap. 2018, 72, 691-696.

[14] H. Gao, J. Zhang, Chem. Eur. J. 2012, 18, $2777-$ 2782.

[15] a) X. Liu, Z. Pan, X. Shu, X. Duan, Y. Liang, Synlett 2006, 1962-1964; b) K. Mal, A. Sharma, I. Das, Chem. Eur. J. 2014, 20, 11932-11945.

[16] a) F. Liu, Y. Yu, J. Zhang, Angew. Chem. Int. Ed. 2009, 48, 5505-5508; b) H. Gao, X. Zhao, Y. Yu, J. Zhang, Chem. Eur. J. 2010, 16, 456-459; c) H. Gao, X. Wu, J. Zhang, Chem. Eur. J. 2011, 17, 2838-2841; d) L. Zhou, M. Zhang, W. Li, J. Zhang, Angew. Chem. Int. Ed. 2014, 53, $6542-$ 6545; e) S. Liu, P. Yang, S. Peng, C. Zhu, S. Cao, J. Li, J. Sun, Chem. Commun. 2017, 53, 11521155 ; f) For a review on gold-catalyzed cascade reactions for synthesis of carbo- and heterocycles based on 2-(1-alkynyl)-2-alken-1-ones transformations see: Q. Deyun, Z. Junliang, Chem. Rec. 2014, 14, 280-302.

[17] a) F. Liu, D. Qian, L. Li, X. Zhao, J. Zhang, Angew. Chem. Int. Ed. 2010, 49, 6669-6672; b) Z.-M. Zhang, P. Chen, W. Li, Y. Niu, X.-L. Zhao, J. Zhang, Angew. Chem. Int. Ed. 2014, 53, 43504354; c) Y. Wang, P. Zhang, D. Qian, J. Zhang, Angew. Chem. Int. Ed. 2015, 54, 14849-14852.

[18] V. Rauniyar, Z. J. Wang, H. E. Burks, F. D. Toste, J. Am. Chem. Soc. 2011, 133, 8486-8489.

[19] Furans are versatile building blocks (M. Maier, in Organic Synthesis Highlights II, Wiley-VCH Verlag GmbH, 2008, pp. 231-242; B. Philippe, P. Evelyne, Eur. J. Org. Chem. 2009, 6075-6089; A. Blanc, V. Beneteau, J.-M. Weibel, P. Pale, Org. Biomol. Chem. 2016, 14, 9184-9205). They are found notably in a number of natural and bioactive compounds (Y. Li, B.-J. Li, Y. Ling, H.J. Miao, Y.-X. Shi, X.-L. Yang, J. Agric. Food Chem. 2010, 58, 3037-3042), materials (P. Huang, J. Du, M. C. Biewer, M. C. Stefan, J. Mater. Chem. A 2015, 3, 6244-6257; A. Kivrak, Ö. F. Er, H. Kivrak, Y. Topal, M. Kuş, Y. Çamlısoy, Opt. Mater. 2017, 73, 206-212), fragrances and flavors (J. Nowicki, J. Kula, D. Hammad, Flavour Fragr. J. 2002, 17, 203-206; M. Ash, I. Ash, Handbook of Flavors and Fragrances, Synapse Information Resources, 2006).

[20] a) E. Mizushima, T. Hayashi, M. Tanaka, Org. Lett. 2003, 5, 3349-3352; b) Z.-Y. Han, H. Xiao, X.-H. Chen, L.-Z. Gong, J. Am. Chem. Soc. 2009, $131,9182-9183$. 
[21] Y. Deng, L. Liu, R. G. Sarkisian, K. Wheeler, H. Wang, Z. Xu, Angew. Chem. Int. Ed. 2013, 52, 3663-3667.

[22] Other silver salts such as $\mathrm{AgNO}_{3}, \mathrm{AgNTf}_{2}$ and $\mathrm{AgPF}_{6}$ promote the catalytic reaction with moderate to good conversion rates $(50,60$ and $>95 \%$ respectively).

[23] a) N. G. Connelly, W. E. Geiger, Chem. Rev. 1996, 96, 877-910; b) M. M. Flores-Leonar, R. Moreno-Esparza, V. M. Ugalde-Saldívar, C. Amador-Bedolla, Comput. Theor. Chem. 2017, 1099, 167-173.

[24] For comparison purposes, when using the chiral catalyst $(R)$-C the same products were obtained in similar yields but with lower enantiomeric excesses, in a range from $63-73 \%$ (see SI for the exact values of ee for compounds 3a-e).

[25] When using catalyst $(R)-\mathbf{C}$, the same drop of yield $(24 \%)$ and enantiomeric excess $(37 \%$ ee) were observed for compound $\mathbf{3 e}$ (see SI).

[26] More nucleophilic amines such as $\mathrm{PhCH}_{2} \mathrm{NH}_{2}$ can't be used in this reaction, since they are known to add spontaneously to the alkyne function of 1a (A. Urbanaitè, L. Šteinys, A. Brukštus, I. Čikotienè, Eur. J. Org. Chem. 2017, 1624-1627).

[27] P. R. Verhoest, R. L. Hoffman, J. W. Corbett, M. D. Ennis, K. E. Frank, J.-M. Fu, 2003, WO2003045924A1, Pharmacia \& Upjohn Company, USA.

[28] N. A. Tamayo, Y. Bo, V. Gore, V. Ma, N. Nishimura, P. Tang, H. Deng, L. Klionsky, S. G. Lehto, W. Wang, B. Youngblood, J. Chen, T. L. Correll, M. D. Bartberger, N. R. Gavva, M. H. Norman, J. Med. Chem. 2012, 55, 1593-1611.

[29] Y. Banno, R. Hara, R. Tokunoh, 2009, WO2009057784A1, Takeda Pharmaceutical Company Limited, Japan.

[30] CCDC 1572999 for 4b and CCDC 1573000 for 4c contain the supplementary crystallographic data for this paper. These data can be obtained free of charge from The Cambridge Crystallographic Data Centre via URL www.ccdc.cam.ac.uk/data_request/cif.

[31] J. L. Arbour, H. S. Rzepa, J. Contreras-García, L. A. Adrio, E. M. Barreiro, K. K. Hii, Chem. Eur. J. 2012, 18, 11317-11324. 


\section{FULL PAPER}

Paracyclophane-based Silver Phosphates as

Catalysts for Enantioselective

Cycloisomerization/Addition Reactions: Synthesis of Bicyclic Furans

Adv. Synth. Catal. 2018, 360, 3356 - 3366

Guillaume Force, ${ }^{\mathrm{a}}$ Yvette Lock Toy $\mathrm{Ki},{ }^{a}$ Kévin Isaac, ${ }^{\mathrm{a}}$ Pascal Retailleau, ${ }^{\mathrm{a}}$ Angela Marinetti ${ }^{\mathrm{a}, *}$ and Jean-François Betzer ${ }^{\mathrm{a}, *}$

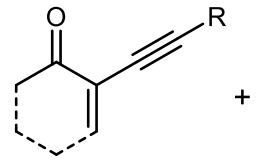

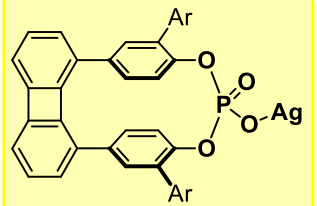

or $(R)$-TRIP-Ag

$\mathrm{Nu}-\mathrm{H}$

- C-nucleophiles

- $N$-nucleophiles

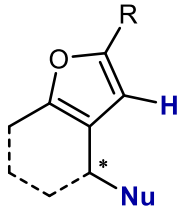

- ee up to $86 \%$ 